DR ROBERTO ROMERO (Orcid ID : 0000-0002-4448-5121)

DR NARDHY GOMEZ-LOPEZ (Orcid ID : 0000-0002-3406-5262)

Article type

: Original Article

\title{
Are B Cells Altered in the Decidua of Women with Preterm or Term Labor?
}

Yaozhu Leng ${ }^{1,2}$, Roberto Romero ${ }^{1,3-5}$, Yi Xu ${ }^{1,2}$, Jose Galaz ${ }^{1,6}$, Rebecca Slutsky ${ }^{1}$, Marcia Arenas-Hernandez ${ }^{1,2}$, Valeria Garcia-Flores ${ }^{1,2}$, Kenichiro Motomura ${ }^{1,2}$, Sonia S. Hassan ${ }^{1,2,7}$, Andrea Reboldi ${ }^{8}$, Nardhy Gomez-Lopez ${ }^{1,2,9}$

Running title: Decidual $B$ cells in preterm and term labor

${ }^{1}$ Perinatology Research Branch, Division of Obstetrics and Maternal-Fetal Medicine, Division of Intramural Research, Eunice Kennedy Shriver National Institute of Child Health and Human Development, National Institutes of Health, U.S. Department of Health and Human Services, Bethesda, Maryland, and Detroit, Michigan, USA

${ }^{2}$ Department of Obstetrics and Gynecology, Wayne State University School of Medicine, Detroit, Michigan, USA

${ }^{3}$ Department of Obstetrics and Gynecology, University of Michigan, Ann Arbor, Michigan, USA

${ }^{4}$ Department of Epidemiology and Biostatistics, Michigan State University, East Lansing, Michigan, USA

${ }^{5}$ Center for Molecular Medicine and Genetics, Wayne State University, Detroit, Michigan, USA

${ }^{6}$ Department of Obstetrics and Gynecology, Faculty of Medicine, Pontificia Universidad Católica de Chile, Santiago, Chile

${ }^{7}$ Department of Physiology, Wayne State University School of Medicine, Detroit, Michigan, USA 
${ }^{8}$ Department of Pathology, University of Massachusetts Medical School, Worcester, Massachusetts, USA

${ }^{9}$ Department of Immunology, Microbiology and Biochemistry, Wayne State University School of Medicine, Detroit, Michigan, USA

Correspondence: Nardhy Gomez-Lopez, PhD, Department of Obstetrics and Gynecology, Wayne State University School of Medicine, Perinatology Research Branch, NICHD/NIH/DHHS, 275 E. Hancock, Detroit, MI 48201, USA, Telephone: (313) 577-8904, E-mail: nardhy.gomez-lopez@wayne.edu.

ACKNOWLEDGEMENTS: This research was supported, in part, by the Perinatology Research Branch (PRB), Division of Intramural Research, Eunice Kennedy Shriver National Institute of Child Health and Human Development, National Institutes of Health, U.S. Department of Health and Human Services (NICHD/NIH/DHHS), and, in part, with federal funds from the NICHD/NIH/DHHS under Contract No.HHSN275201300006C. This research was also supported by the Wayne State University Perinatal Initiative in Maternal, Perinatal and Child Health. We thank the physicians and nurses from the Center for Advanced Obstetrical Care and Research and the Intrapartum Unit, as well as the research assistants from the PRB Clinical Laboratory, for their help in collecting samples. We also thank staff members of the PRB Histology/Pathology Unit for the processing and examination of the pathological sections.

\section{CONFLICT OFINTEREST STATEMENT}

The authors declare no potential conflicts of interest.

\section{ABSTRACT}

Problem: The immunophenotype of B cells at the maternal-fetal interface (decidua) in labor at term and preterm labor is poorly understood.

Method of study: Decidual tissues were obtained from women with preterm or term labor and from non-labor gestational age-matched controls. Immunophenotyping of decidual $\mathrm{B}$ cells was performed using multi-color flow cytometry.

Results: 1) In the absence of acute or chronic chorioamnionitis, total $B$ cells were more abundant in the decidua parietalis of women who delivered preterm than those who 
delivered at term, regardless of the presence of labor; 2) decidual transitional and naïve B cells were the most abundant B-cell subsets; 3 ) decidual B1 B cells were increased in women with labor at term or preterm labor and chronic chorioamnionitis compared to those without this placental lesion; 4) decidual transitional B cells were reduced in women with preterm labor compared to those without labor; 5) naïve, class-switched, and non-class-switched $B$ cells in the decidual tissues underwent mild alterations with the process of preterm labor and/or placental inflammation; 6) decidual plasmablasts seemed to increase in women with labor at term or preterm labor with chronic chorioamnionitis; and 7) decidual B cells expressed high levels of interleukin (IL)-12, IL6 and/or IL-35.

Conclusions: Total B cells are not increased with the presence of preterm or term labor; yet, specific subsets (B1 and plasmablasts) undergo alterations in women with chronic chorioamnionitis. Therefore, B cells are solely implicated in the pathological process of preterm labor in a subset of women with chronic inflammation of the placenta. These findings provide insight into the immunology of the maternal-fetal interface in preterm and term labor.

Keywords: B1 B cells, chronic chorioamnionitis, funisitis, memory B cells, naïve B cells, placental inflammation, plasmablasts, pregnancy, transitional B cells

\section{INTRODUCTION}

Preterm labor, which commonly precedes preterm birth ${ }^{1,2}$, is a syndrome involving multiple pathological processes ${ }^{3,4}$. Among the known mechanisms, pathological inflammation is the best-characterized causal link to preterm labor and birth 5-14. To date, the most studied causes of pathological inflammation leading to preterm labor have been 1) intra-amniotic infection/inflammation resulting from microbial invasion of the amniotic cavity 5, 7, 8, 15-33, and 2) intra-amniotic inflammation without detectable microorganisms (i.e. sterile intra-amniotic inflammation) identified by using both molecular and conventional microbiological techniques ${ }^{32,34-38}$, proposed to be due to endogenous danger signals, or alarmins ${ }^{39-49}$. Most research concerning inflammation-induced preterm labor has therefore focused on the innate limb of immunity ${ }^{50-73}$. Yet, several studies reported strong evidence that $\mathrm{T}$ cells, the primary 
cellular component of the adaptive immune system, are present at the maternal-fetal interface ${ }^{74-89}$. More recently, we provided evidence indicating that $T$ cells are also implicated in the mechanisms that lead to labor at term ${ }^{84,85}$ and spontaneous preterm labor ${ }^{90-97}$. However, B cells, the main humoral component of adaptive immunity, have been less investigated.

B cells were first described in the placental bed of women early in gestation ${ }^{98}$, which was confirmed by later studies ${ }^{99,100}$. During early pregnancy, B cells are implicated in the mechanisms of maternal-fetal tolerance ${ }^{101-115}$. Decidual B cells modestly increased between 27 and 33 weeks of gestation followed by a slight decline at term ${ }^{100}$. In the absence of labor at term, multiple studies reported that B cells are present at the human maternal-fetal interface (i.e. decidua basalis and decidua parietalis) ${ }^{76,77,99,116,117}$. Moreover, B cells seem to be increased in the decidua basalis 77 , but not in the decidua parietalis ${ }^{77,116}$, during the physiological process of labor at term. A recent study provided evidence indicating a role for $B$ cells in the pathogenesis of preterm labor: the results showed increased proportions of $B$ cells in the decidua parietalis of women who underwent spontaneous preterm labor compared to those with labor at term ${ }^{118}$. However, this study did not include gestational age-matched controls, allowing for further investigation of the B-cell compartment at the human maternal-fetal interface in both labor at term and preterm labor.

In the current study, we performed immunophenotyping of the decidua basalis and decidua parietalis of women who underwent the physiological process of labor at term or the syndrome of preterm labor leading to preterm birth. Decidual tissues from gestational age-matched controls were also included. In addition, the B-cell subsets in acute and chronic maternal inflammatory lesions of the placenta were compared. Lastly, the production of cytokines by decidual $B$ cells was determined.

\section{MATERIALS AND METHODS}

\section{Human subjects, clinical specimens, and definitions}

Samples of the human placental basal plate (maternal side of the placenta, decidua basalis) and chorioamniotic membranes (amnion, chorion, and decidua parietalis) were collected from patients within 30 minutes after delivery at Hutzel Women's Hospital in the Detroit Medical Center, Detroit, MI, USA, in partnership with 
Wayne State University School of Medicine and the Perinatology Research Branch, an intramural program of the Eunice Kennedy Shriver National Institute of Child Health and Human Development, National Institutes of Health, U. S. Department of Health and Human Services (NICHD/NIH/DHHS), Detroit, MI, USA. The collection and utilization of biological materials for research purposes were approved by the Institutional Review Boards of Wayne State University and NICHD. All participating women provided written informed consent prior to the collection of samples.

The study groups included women who delivered at term with labor (TIL) or without labor (TNL) and women who delivered preterm with labor (PTL) or without labor (PTNL). Preterm birth was defined as delivery before 37 weeks of gestation. Labor was defined by the presence of regular uterine contractions at a frequency of at least 2 contractions every 10 minutes with cervical changes resulting in delivery. The TIL and PTL study groups were subdivided based on the presence of acute histologic chorioamnionitis (ACA) and chronic histologic chorioamnionitis (CCA) (see "Placental histopathological examination" section for diagnostic criteria). Patients with neonates having congenital or chromosomal abnormalities were excluded from this study. The clinical and demographic characteristics of the study population are shown in Tables 1 and 2. Both the decidua basalis and decidua parietalis were collected from most patients; however, the decidua basalis was not available in a few cases. Therefore, Table 1 describes patients from which the decidua basalis was available, and Table 2 describes patients from which the decidua parietalis was available for experiments.

\section{Placental histopathological examination}

Placentas were examined histologically by a perinatal pathologist blinded to clinical diagnoses and obstetrical outcomes according to standardized Perinatology Research Branch protocols. Briefly, three to nine sections of the placenta were examined, and at least one full-thickness section was taken from the center of the placenta; other sections were taken randomly from the placental disc. Acute and chronic inflammatory lesions of the placenta (maternal inflammatory response and fetal inflammatory response) were diagnosed according to established criteria, including staging and grading ${ }^{94,119-122}$. Maternal acute placental inflammation was defined by the 
infiltration of neutrophils into the chorion and amnion, termed acute histologic chorioamnionitis (ACA) ${ }^{119,121}$. Maternal chronic histologic chorioamnionitis (CCA) was defined as lymphocytic infiltration into the chorionic trophoblast layer or chorioamniotic connective tissue ${ }^{90,94}$.

\section{Decidual leukocyte isolation}

Decidual leukocytes were isolated from the decidual tissue of patients from each study group as previously described ${ }^{123}$. Briefly, the decidua basalis was collected from the basal plate of the placenta, and the decidua parietalis was separated from the chorioamniotic membranes. The decidual tissues were homogenized in StemPro Accutase Cell Dissociation Reagent (Life Technologies, Grand Island, NY, USA) using a gentleMACS Dissociator (Miltenyi Biotec, San Diego, CA, USA). Homogenized tissues were incubated in Accutase for $45 \mathrm{~min}$ at $37^{\circ} \mathrm{C}$ with gentle agitation. After incubation, tissues were washed in 1X phosphate-buffered saline (PBS; Life Technologies) and

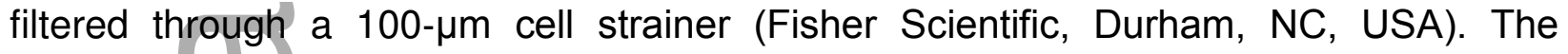
resulting cell suspensions were centrifuged at $300 \times \mathrm{g}$ for $10 \mathrm{~min}$ at $4^{\circ} \mathrm{C}$. The decidual mononuclear cells were then separated using a density gradient (Ficoll-Paque Plus; GE Healthcare Biosciences, Piscataway, NJ, USA) in accordance with the manufacturer's instructions. The cells collected from the mononuclear layer of the density gradient were washed with 1X PBS and immediately used for immunophenotyping.

\section{Immunophenotyping of decidual B cells}

Mononuclear cell suspensions from decidual tissues were stained with the LIVE/DEAD Fixable Yellow Dead Cell Stain Kit (ThermoFisher Scientific/Molecular Probes, Eugene, OR, USA) prior to immunophenotyping. Mononuclear cell suspensions were then washed with stain buffer (CAT\#554656; BD Biosciences, San Jose, CA, USA) and incubated with $20 \mu \mathrm{L}$ of human FcR Blocking Reagent (CAT\#130-059-901; Miltenyi Biotec) in $80 \mu \mathrm{L}$ of stain buffer for $10 \mathrm{~min}$ at $4^{\circ} \mathrm{C}$. The cells were incubated with extracellular fluorochrome-conjugated anti-human monoclonal antibodies for $30 \mathrm{~min}$ at $4^{\circ} \mathrm{C}$ in the dark (Supplementary Table 1). Stained cells were washed and resuspended in $0.5 \mathrm{~mL}$ of FACS staining buffer and acquired using an LSRII flow cytometer and 
FACSDiva 6.0 software (BD Biosciences). The absolute number of cells was determined using CountBright absolute counting beads (Life Technologies, Molecular Probes). The analysis and figures were performed using FlowJo software version 10 (FlowJo, LLC, Ashland, OR, USA). Lymphocytes were gated using forward scatter (FSC) verse side scatter (SSC). B cells were gated as $\mathrm{CD} 19^{+} \mathrm{CD} 3^{-}$cells within the lymphocytic and viability gates (Figure 1B). The cell surface markers (Supplementary Table 1) used to identify the different B-cell subsets were determined by an extensive literature search (Table 3). Cytokine expression by decidual B cells was also performed using specific monoclonal antibodies directly after isolation from the tissue without stimulation (Supplementary Table 1).

\section{Statistics}

Statistical analyses were conducted using SPSS software version 19.0 (IBM Corporation, Armonk, NY, USA). The Mann-Whitney U-test was used for comparisons between the two study groups. Two-tailed ( $p$-values without an asterisk) or one-tailed ( $p$-values with an asterisk) $p$-values were reported. The Friedman test was used for comparisons between decidual tissues and blood samples collected from the same patients. For patient demographics, the Kruskall-Wallis test was performed for continuous variables and the Fisher's exact test for nominal variables. A p-value $<0.05$ was considered statistically significant.

\section{RESULTS}

In the absence of acute or chronic chorioamnionitis, total B cells are more abundant in the decidua parietalis of women who delivered preterm than in those who delivered at term, regardless of the process of labor

Figure $1 \mathrm{~A}$ shows the spatial localization of the decidua basalis and decidua parietalis. The gating strategy used to identify total B cells is shown in Figure 1B. First, we compared the proportion of total $B$ cells in the decidual tissues to those in the maternal blood and cord blood. The frequency of $B$ cells in the decidua basalis and decidua parietalis was lower than that observed in maternal blood and cord blood (Figure $1 \mathrm{C}$ ). Most of the $\mathrm{B}$ cells present in the decidua basalis and decidua parietalis co- 
expressed CD20, as did the B cells in maternal blood and cord blood (Figure 1D). Additionally, a CD19+CD20 subset was present in decidual tissues but rarely found in maternal blood and cord blood (Figure 1D). The number of B cells in the decidua basalis and decidua parietalis ranged from $2 \times 10^{2}$ to $2 \times 10^{5}$ cells (Supplementary Figure 1 ), considerably lower than previously reported ${ }^{118}$. Yet, our finding is consistent with previous studies indicating that the B-cell population is a small fraction among decidual leukocytes ${ }^{85,123}$. Preterm placentas are significantly smaller than term placentas and the amount of decidual tissue available varies among patients; therefore, flow cytometry quantification may not allow calculation of the absolute number of decidual B cells. For this reason, we used frequencies, also referred to as proportions, throughout the study.

In the decidua basalis, the total number of $B$ cells did not vary among the term and preterm groups (TNL vs TIL vs PTNL vs PTL, Figure 1E). Further, no differences were observed among those groups when samples were allocated into subgroups comparing acute and chronic inflammatory lesions of the placenta (Figure 1F). In the decidua parietalis, the total number of $B$ cells did not vary among term and preterm groups when placental inflammation was not considered (TNL vs TIL vs PTNL vs PTL, Figure $1 \mathrm{G}$ ). In the absence of acute or chronic chorioamnionitis, the decidua parietalis of women who delivered preterm had higher proportions of $B$ cells than those who delivered at term, regardless of the presence of labor (PTNL or PTL vs TNL or TIL, Figure $1 \mathrm{H}$ ). The data indicate that $\mathrm{B}$ cells are more abundant in preterm gestation than at term, consistent with findings previously reported ${ }^{100}$. Yet, contrary to what has been reported ${ }^{77,118}$, the processes of preterm and term labor did not alter the frequency of total B cells. In the decidua parietalis, B cells were more abundant in women with chronic chorioamnionitis who underwent labor at term compared to those without this placental lesion (TIL with CCA vs TIL or TIL with ACA, Figure $1 \mathrm{H}$ ). However, no differences were observed in B-cell frequencies between the PTL and PTL with CCA groups.

\section{Identification of different B-cell subsets in the decidual tissues}

Next, we performed an extensive literature review of the markers used to identify the main B-cell subsets (Table 3). Two main B-cell subsets have been described: B1 
and B2 B cells ${ }^{124}$ (Figure 2A). Both B1 and B2 B cells can become transitional B cells, naïve $B$ cells, class-switched memory $B$ cells, non-class-switched memory $B$ cells, and plasmablasts ${ }^{124}$ (Figure 2B). CD19+ $\mathrm{B}$ cells were subdivided into the above-mentioned B-cell subsets. The gating strategy used to identify these B-cell subsets is shown in Figure $2 \mathrm{C}$. We found that $\mathrm{B} 2 \mathrm{~B}$ cells were more abundant in the decidual tissues than B1 B cells, which made up a distinct but very small population (data not shown). Therefore, the B1 B cells were considered by themselves. A t-SNE plot showing the different B-cell subsets identified in the decidual tissues is shown in Figure 2D. Transitional and naïve $B$ cells were the most abundant subsets in the decidual tissues (Figure 2D).

\section{B1 B cells are increased in the decidual tissues of women with chronic chorioamnionitis who underwent labor at term or preterm labor}

$B 1 B$ cells were rarely found in the decidual tissues, as shown in the t-SNE plot (Figure $3 \mathrm{~A}$ ). In the decidua basalis, the frequency of $\mathrm{B} 1 \mathrm{~B}$ cells did not change between the labor and no labor groups (TNL vs TIL and PTNL vs PTL, Figure 3B). A higher proportion of B1 B cells was observed in women who underwent preterm labor compared to those who underwent labor at term (PTL vs TIL, Figure 3B). This difference was most likely driven by the presence of chronic chorioamnionitis in the preterm labor group (PTL with CCA, Figure $3 \mathrm{C}$ ). The presence of chronic chorioamnionitis also increased the proportion of B1 B cells in labor at term (TIL with CCA vs TIL or TIL with ACA, Figure $3 \mathrm{C}$ ). In the decidua parietalis, B1 B cells were less abundant in women who underwent labor at term compared to those who delivered at term without labor (TIL vs TNL, Figure 3D). However, women who underwent labor at term with chronic chorioamnionitis had higher proportions of $\mathrm{B} 1 \mathrm{~B}$ cells than those without this placental lesion (TIL with CCA vs TIL, Figure 3E). Women who underwent preterm labor with chronic chorioamnionitis also had higher proportions of $\mathrm{B} 1 \mathrm{~B}$ cells compared to those without this placental lesion (PTL with CCA vs PTL or PTL with ACA, Figure $3 \mathrm{~B}$ ). These results show that $\mathrm{B} 1 \mathrm{~B}$ cells are increased in the decidual tissues of women who underwent labor at term or preterm labor in the presence of chronic 
chorioamnionitis, but not in those with acute chorioamnionitis or without placental lesions.

Transitional B cells were reduced in the decidual tissues of women with preterm labor compared to gestational age-matched controls

Transitional $B$ cells are the critical link between bone marrow immature and mature $B$ cells present in the peripheral repertoire ${ }^{125,126}$. The transitional B-cell subset is thought to represent a key negative selection checkpoint for autoreactive $B$ cells ${ }^{127}$, 128. Transitional $B$ cells were one of the most abundant B-cell subsets present in the decidual tissues, as shown in the t-SNE plot (Figure 4A). In the decidua basalis, the proportion of transitional $B$ cells was lower in women who underwent preterm labor compared to those who delivered preterm in the absence of labor (PTL vs PTNL, Figure 4B). Additionally, transitional B cells were less abundant in women who underwent preterm labor with or without acute or chronic chorioamnionitis compared to those who delivered preterm without labor (PTL with CCA, PTL with ACA, and PTL vs PTNL, Figure 4C). However, transitional $B$ cells were more abundant in women who delivered preterm without labor than in those who delivered at term in the absence of labor (PTNL vs TNL, Figure 4B). In the decidua parietalis, transitional B cells were less abundant in women who underwent preterm labor than in those who delivered preterm without labor (PTL vs PTNL, Figure 4D). Transitional B cells were even fewer in women who underwent preterm labor with chronic chorioamnionitis than in those without this placental lesion (PTL with CCA vs PTL, Figure 4E). Taken together, these data show that transitional $B$ cells are reduced in women with preterm labor compared to gestational age-matched controls.

\section{Naïve B cells undergo mild alterations in the decidual tissues}

Naïve B cells were another abundant B-cell subset found in the decidual tissues, as shown in the t-SNE plot (Figure 5A). In the decidua basalis, naïve B cells did not vary among the study groups (TNL vs TIL vs PTNL vs PTL, Figure $5 B$ ). In the absence of placental lesions, naïve $B$ cells were modestly higher in women who delivered preterm without labor than in those who delivered at term without labor (PTNL vs TNL, Figure 
5C). In the decidua parietalis, naïve B cells were reduced in women who underwent preterm labor compared to those who delivered preterm without labor (PTL vs PTNL, Figure 5D). This reduction was driven by the presence of chronic chorioamnionitis given that women who underwent preterm labor with this placental lesion tended to have fewer naïve $\mathrm{B}$ cells in the decidua parietalis (Figure $5 \mathrm{E}$ ). Women with preterm labor and chronic chorioamnionitis had fewer naïve $B$ cells than those with labor at term and this placental lesion (PTL with CCA vs TIL with CCA, Figure 5E). In summary, naïve B cells undergo mild alterations in the decidua basalis of women with preterm labor and chronic chorioamnionitis.

\section{Class-switched and non-class-switched memory B cells are rare and undergo mild alterations in the decidual tissues}

Naïve B cells can undergo class-switch recombination generating class-switched or non-class-switched memory B cells ${ }^{129}$. Next, we examined whether these B-cell subsets were present in the decidual tissues. Class-switched and non-class-switched memory $B$ cells were rarely present in the decidual tissues (Figures $6 A$ and $7 A$ ). In the decidua basalis, class-switched memory $B$ cells were more abundant in women who underwent preterm labor than in those with labor at term (PTL vs TIL, Figure 6B). This increase was most likely due to the presence of chronic chorioamnionitis since women who underwent preterm labor with this placental lesion tended to have higher proportions of class-switched memory B cells than those without it (PTL with CCA vs PTNL, PTL, or PTL with ACA, Figure 6C). In the absence of placental lesions, classswitched memory $B$ cells were less abundant in women who underwent labor at term (TIL vs TNL, Figure 6C). However, class-switched memory B cells were more abundant in women who underwent labor at term with chronic chorioamnionitis than in those with acute chorioamnionitis (TIL with CCA vs TIL with ACA, Figure $6 \mathrm{C}$ ). In the decidua parietalis, class-switched memory $B$ cells were less abundant in women with labor at term than in those who delivered at term without labor (TIL vs TNL, Figure 6D), which was consistently observed in the absence of placental lesions (Figure 6E). No differences were observed between women who delivered preterm with and without labor (PTNL vs PTL, Figure 6D). In summary, in the absence of placental lesions, class- 
switched memory B cells are rare in the decidual tissues and undergo mild alterations with the presence of labor and/or placental inflammation.

Non-class-switched memory B cells were even less abundant than classswitched memory $B$ cells in the decidual tissues (Figure 7A). In the decidua basalis, non-class-switched memory B cells did not vary among the study groups (TNL vs TIL vs PTNL vs PTL, Figure 7B). When the patients were divided into subgroups according to the presence of placental lesions, a slight increase in the proportion of non-classswitched memory B cells was observed in women who underwent labor at term with chronic chorioamnionitis compared to those with acute chorioamnionitis (TIL with CCA vs TIL with ACA, Figure $7 C$ ). In the decidua parietalis, non-class-switched memory $B$ cells were less abundant in women who underwent preterm labor than those who delivered preterm without labor (PTL vs PTNL, Figure 7D). This was most likely driven by the presence of chronic chorioamnionitis since women with this placental lesion had lower proportions of this B-cell subset than those without it (PTL with CCA vs PTL and PTNL, Figure 7E). In the absence of placental lesions, a small reduction in the proportion of non-class-switched memory B cells was also observed in women with labor at term compared to those without labor (TIL vs TNL, Figure 7E). However, women who underwent labor at term with chronic chorioamnionitis had greater proportions of non-class-switched memory $B$ cells than those without this placental lesion (TIL with CCA vs TIL, Figure 7E). Therefore, in the absence of placental lesions, non-class-switched memory $B$ cells are rare in the decidual tissues and undergo mild alterations with the presence of labor and/or placental inflammation.

\section{Plasmablasts seemed to increase in the decidual tissues of women with chronic chorioamnionitis who underwent labor at term or preterm labor}

Naïve B cells and memory B cells can differentiate into plasmablasts ${ }^{129,}{ }^{130}$. We then investigated the presence of plasmablasts in the decidual tissues. Plasmablasts were a relatively abundant population in the decidual tissues (Figure 8A). In the decidua basalis and decidua parietalis, plasmablasts did not vary among the study groups (TNL vs TIL vs PTNL vs PTL, Figures $8 B$ \& $8 D$ ). When the samples were divided into subgroups according to the presence of placental lesions, we consistently found that 
women who underwent labor at term with chronic chorioamnionitis had higher proportions of plasmablasts than those without this placental lesion in both the decidua basalis and decidua parietalis (TIL with CCA vs TIL or TIL with ACA, Figures $8 \mathrm{C} \& 8 \mathrm{E}$ ). Plasmasblasts seemed to be more abundant in women who underwent preterm labor with CCA than in those without this placental lesion (Figures $8 \mathrm{C} \& 8 \mathrm{E}$ ). Taken together, these data show that plasmablasts are abundant in the decidual tissues of women who underwent labor at term or preterm labor with chronic chorioamnionitis.

\section{B cells in the decidual tissues expressed high levels of IL-12, IL-6 and/or IL35}

Recent studies indicated that, besides production of antibodies, B cells participate in immune responses by producing inflammatory cytokines ${ }^{131},{ }^{132}$. We investigated whether decidual B cells produce pro- and anti-inflammatory cytokines that are associated with the process of labor. In the decidua basalis and decidua parietalis, a small proportion of $B$ cells expressed cytokines (Figure 9A \& 9C). In the decidua basalis, B cells expressed higher levels of interleukin (IL)-12 and IL-35 than IFNY, IL-2, IL-4, IL-6, IL-10, and TNFa (Figure 9B). In the decidua parietalis, B cells expressed higher levels of IL-12 and IL-6 than other cytokines (Figure 9D). These results show that $B$ cells participate in the inflammatory milieu at the maternal-fetal interface.

\section{DISCUSSION}

\section{Principal findings}

The principal findings of this study are as follows: 1) In the absence of acute or chronic chorioamnionitis, total B cells were more abundant in the decidua parietalis of women who delivered preterm than in those who delivered at term, regardless of the presence of labor; 2) decidual transitional and naïve B cells were the most abundant B-cell subsets; 3) decidual B1 B cells were increased in women with labor at term or preterm labor with chronic chorioamnionitis compared to those without this placental lesion; 4) decidual transitional $\mathrm{B}$ cells were reduced in women with preterm labor compared to those without labor; 5) decidual naïve B cells underwent mild alterations with the process of preterm labor and/or placental inflammation; 6) class-switched and nonclass-switched memory $B$ cells were rare and underwent mild alterations with the 
process of labor and/or placental inflammation; 7) decidual plasmablasts seemed to increase in women with labor at term or preterm with chronic chorioamnionitis; and 8) decidual $B$ cells expressed high levels of IL-12, IL-6, or IL-35. These findings indicate that specific B-cell populations at the maternal-fetal interface undergo alterations in a subset of women with labor at term and preterm labor and chronic chorioamnionitis.

In the absence of acute or chronic chorioamnionitis, total B cells were more abundant in the decidua parietalis of women who delivered preterm than in those who delivered at term, regardless of the presence of labor

Herein, we found that total B cells were not increased in the decidua basalis and decidua parietalis of women who underwent labor at term compared to those who delivered at term without labor. This finding is consistent, in part, with what has previously been published. We and other investigators have reported that there are no differences in the proportion of $B$ cells in the decidua parietalis of women who delivered at term with and without labor ${ }^{77,85}$. However, previous studies have shown that the decidua basalis of women who underwent spontaneous labor at term had greater proportions of total $\mathrm{B}$ cells than those who delivered at term without labor ${ }^{77}$. The discrepancy between the above-mentioned study and our findings could be explained by the fact that we considered only viable $B$ cells. These findings show that the frequency of total viable $B$ cells is not altered with the physiological process of labor at term.

We also found that total B cells were not increased in the decidua basalis and decidua parietalis of women who underwent preterm labor compared to those who delivered preterm in the absence of labor. To our knowledge, it is the first time that this comparison between preterm labor cases and gestational age-matched controls has been made. A previous study reported that the abundance of $B$ cells in the decidua parietalis was significantly increased in women who underwent spontaneous preterm labor compared to those who underwent spontaneous labor at term ${ }^{118}$. However, this comparison warrants caution given that gestational age may influence the proportion of $B$ cells found in the decidual tissues ${ }^{100}$. Without considering acute and chronic chorioamnionitis, no differences in the frequency of total $B$ cells in the decidua parietalis 
were observed between women who underwent preterm labor and those with term labor. Women with preterm labor, but without acute or chronic chorioamnionitis, had higher frequencies of decidual B cells compared to those with labor at term. Nonetheless, this increase in the proportion of total B cells was also observed by comparing women who delivered preterm in the absence of labor to those who delivered at term without labor. Therefore, these data indicate that the process of preterm labor does not increase the proportion of total B cells in the decidua parietalis; rather, it is an effect of gestational age.

After the two study groups were subdivided based on the presence of acute or chronic chorioamnionitis, we found that the frequency of total B cells in the decidua basalis did not significantly vary. Yet, differences in B-cell proportions in the decidua parietalis were observed among the study groups. This result is explained by the fact that acute and chronic chorioamnionitis are diagnosed in the chorioamniotic membranes, located next to the decidua parietalis ${ }^{94,121}$. Of interest, the presence of chronic chorioamnionitis increased the frequency of total $B$ cells in the decidua parietalis of women with labor at term but not in those with preterm labor (Figure $1 \mathrm{H}$ ). These findings suggest that the process of chronic chorioamnionitis in labor at term is distinct from that observed in women with preterm labor.

Different B-cell subsets were present in the decidual tissues; yet, we focused our discussion on the main differences observed in women with labor at term and those with preterm labor.

\section{Decidual B1 B cells are increased in women with chronic chorioamnionitis who underwent labor at term or preterm labor}

$B 1$ B cells show a skewed antigen receptor repertoire toward self-antigens, as well as tonic B-cell receptor intracellular signaling, spontaneous secretion of $\operatorname{lgM}$, and efficient T-cell stimulation ${ }^{133}$. Herein, we found that B1 B cells are increased in the decidua basalis and decidua parietalis of women with labor at term or preterm labor with chronic chorioamnionitis. These data suggest, for the first time, a role for decidual B1 B cells in the pathological process of chronic chorioamnionitis associated with either labor at term or preterm labor. Potentially, B1 B cells could be participating in the stimulation 
of $\mathrm{CD8}^{+}$cytotoxic $\mathrm{T}$ cells, which can induce apoptosis of trophoblasts leading to maternal anti-fetal rejection ${ }^{94}$. More recently, we found that both decidual $\mathrm{CD} 4^{+}$and $\mathrm{CD8}^{+} \mathrm{T}$ cells from women who underwent spontaneous preterm labor displayed an effector memory phenotype and expressed high levels of granzyme B and perforin ${ }^{97}$, molecules capable of cytotoxicity ${ }^{134-140}$. B1 B cells constitutively secrete IL-10 ${ }^{141}$, suggesting that these cells are implicated in the regulation of such a chronic inflammatory process associated with labor at term and preterm labor. Given that B1 B cells are either pro-inflammatory (through cytotoxic $\mathrm{CD}^{+}{ }^{+} \mathrm{T}$-cell stimulation) or antiinflammatory (through IL-10 secretion), their role may vary in chronic chorioamnionitis and requires further investigation.

\section{Decidual naïve B cells undergo mild alterations with the process of preterm labor and/or placental inflammation}

During a primary response, transitional $B$ cells differentiate to naïve $B$ cells that upon a secondary response can generate memory B cells ${ }^{142}$. Naïve $B$ cells and memory $\mathrm{B}$ cells display differential expression of $\operatorname{lgD}$ or CD27 and in vitro function following BCR stimulation ${ }^{143-145}$. Overall, naïve B cells present antigen-inexperienced responses compared to memory $B$ cells ${ }^{145}$. Naïve $B$ cells can also proliferate into shortlived plasmablasts or plasma cells that produce low-affinity antibodies ${ }^{146}$. In the current study, we found that naïve B cells were reduced in patients with preterm labor and chronic chorioamnionitis, but no differences were observed in memory B cells. Yet, decidual tissues from women who underwent preterm labor with chronic chorioamnionitis tended to have greater proportions of plasmablasts. These data suggest that, in women with preterm labor and chronic chorioamnionitis, naïve B cells might proliferate to plasmablasts in the decidual tissues. However, additional investigation of decidual $\mathrm{B}$ cells is required to strengthen this proposed concept.

\section{Decidual plasmablasts increase in women who underwent labor at term or preterm labor with chronic chorioamnionitis}

Plasmablasts are newly differentiated B cells that can leave the lymphoid organs and home in either tissue or bone marrow ${ }^{147,}{ }^{148}$. Additionally, they are capable of 
differentiating into fully mature plasma cells ${ }^{149}$. Plasmablasts are usually short-lived and can be generated inside and outside of the germinal centers ${ }^{150}$. In general, plasmablasts represent an accessible source of mature antibodies characterized by the regulation of several transcription factors, such as BLIMP1 (B-lymphocyte-induced maturation protein 1 ) and IRF4 (interferon-regulatory factor $4{ }^{151}{ }^{15}$. Our results showed that plasmablasts seemed to increase in women who underwent labor at term or preterm labor with chronic chorioamnionitis. These data suggest that, in addition to $T$ cells, the hallmark of chronic chorioamnionitis ${ }^{94}$, B-cell antibody-mediated responses are implicated in the chronic inflammatory process associated with preterm labor and birth.

\section{B cells can express cytokines in the decidual tissues}

Cytokine production by $B$ cells is implicated in multiple aspects of immunity ${ }^{132}$. Thus, B cells can express pro- and anti-inflammatory cytokines to mediate immune responses 131,132. Herein, we found that, in both the decidua basalis and decidua parietalis, B cells expressed high levels of IL-12, a cytokine that increased in the amniotic fluid of women with preterm labor and preterm birth ${ }^{46}$. In the decidua parietalis, B cells also expressed high levels of IL-6, a cytokine released by gestational tissues and highly relevant in the pathological process of preterm labor ${ }^{26,152}$. Therefore, these data provide evidence that, by releasing cytokines, B cells at the maternal-fetal interface contribute to the pro-inflammatory microenvironment associated with labor. B cells, however, could also be participating in the regulation of such a hostile microenvironment, given that these cells also expressed a high level of IL-35, an immunosuppressive cytokine previously reported to be expressed by the placental tissues ${ }^{153}$. Further studies are needed to investigate whether decidual $\mathrm{B}$ cells display different cytokine profiles than those derived from gestational-aged matched controls.

\section{Conclusion}

The current study provides the characterization of B-cell subsets at the human maternal-fetal interface during labor at term and preterm labor. In the absence of acute or chronic chorioamnionitis, total $\mathrm{B}$ cells are more abundant in the decidua parietalis of 
women who delivered preterm than in those who delivered at term, regardless of the process of labor. Yet, an increase in the proportions of B1 B cells and plasmablasts was observed in women who underwent labor at term or preterm labor with chronic chorioamnionitis compared to those without this placental lesion. Decidual B cells are capable of producing pro- and anti-inflammatory cytokines. In conclusion, the B-cell compartment at the maternal-fetal interface undergoes alterations in women with labor at term or preterm labor and chronic chorioamnionitis, suggesting that these adaptive immune cells are implicated in the process of labor associated with chronic inflammation of the placenta. Additional experimentation is required to investigate the functionality of chronic chorioamnionitis-derived B cells.

\section{REFERENCES}

1 Goldenberg RL, Culhane JF, lams JD, Romero R: Epidemiology and causes of preterm birth. Lancet 2008;371:75-84.

2 Muglia LJ, Katz M: The enigma of spontaneous preterm birth. N Engl J Med 2010;362:529-535.

3 Romero R, Mazor M, Munoz H, Gomez R, Galasso M, Sherer DM: The preterm labor syndrome. Ann N Y Acad Sci 1994;734:414-429.

4 Romero R, Dey SK, Fisher SJ: Preterm labor: one syndrome, many causes. Science 2014;345:760-765.

5 Romero R, Mazor M, Wu YK, Sirtori M, Oyarzun E, Mitchell MD, Hobbins JC: Infection in the pathogenesis of preterm labor. Semin Perinatol 1988;12:262-279.

6 Gravett MG, Witkin SS, Haluska GJ, Edwards JL, Cook MJ, Novy MJ: An experimental model for intraamniotic infection and preterm labor in rhesus monkeys. Am J Obstet Gynecol 1994;171:1660-1667.

7 Gomez R, Romero R, Edwin SS, David C: Pathogenesis of preterm labor and preterm premature rupture of membranes associated with intraamniotic infection. Infect Dis Clin North Am 1997;11:135-176. 
8 Romero R, Gotsch F, Pineles B, Kusanovic JP: Inflammation in pregnancy: its roles in reproductive physiology, obstetrical complications, and fetal injury. Nutr Rev 2007;65:S194-202.

9 Vornhagen J, Quach P, Boldenow E, Merillat S, Whidbey C, Ngo LY, Adams Waldorf KM, Rajagopal L: Bacterial Hyaluronidase Promotes Ascending GBS Infection and Preterm Birth. MBio 2016;7.

10 Boldenow E, Gendrin C, Ngo L, Bierle C, Vornhagen J, Coleman M, Merillat S, Armistead B, Whidbey C, Alishetti V, Santana-Ufret V, Ogle J, Gough M, Srinouanprachanh S, MacDonald JW, Bammler TK, Bansal A, Liggitt HD, Rajagopal L, Adams Waldorf KM: Group B Streptococcus circumvents neutrophils and neutrophil extracellular traps during amniotic cavity invasion and preterm labor. Sci Immunol 2016;1.

11 Strauss JF, 3rd, Romero R, Gomez-Lopez N, Haymond-Thornburg H, Modi BP, Teves ME, Pearson LN, York TP, Schenkein HA: Spontaneous preterm birth: advances toward the discovery of genetic predisposition. Am J Obstet Gynecol 2018;218:294-314 e292.

12 Garcia-Flores V, Romero R, Miller D, Xu Y, Done B, Veerapaneni C, Leng Y, Arenas-Hernandez M, Khan N, Panaitescu B, Hassan SS, Alvarez-Salas LM, Gomez-Lopez N: Inflammation-Induced Adverse Pregnancy and Neonatal Outcomes Can Be Improved by the Immunomodulatory Peptide Exendin-4. Front Immunol 2018;9:1291.

13 Presicce P, Park CW, Senthamaraikannan P, Bhattacharyya S, Jackson C, Kong F, Rueda CM, DeFranco E, Miller LA, Hildeman DA, Salomonis N, Chougnet CA, Jobe AH, Kallapur SG: IL-1 signaling mediates intrauterine inflammation and chorio-decidua neutrophil recruitment and activation. JCI Insight 2018;3.

14 Keelan JA: Intrauterine inflammatory activation, functional progesterone withdrawal, and the timing of term and preterm birth. J Reprod Immunol 2018;125:89-99.

15 Bobitt JR, Ledger WJ: Unrecognized amnionitis and prematurity: a preliminary report. J Reprod Med 1977;19:8-12. 
16 Bobitt JR, Ledger WJ: Amniotic fluid analysis. Its role in maternal neonatal infection. Obstet Gynecol 1978;51:56-62.

17 Miller JM, Jr., Pupkin MJ, Hill GB: Bacterial colonization of amniotic fluid from intact fetal membranes. Am J Obstet Gynecol 1980;136:796-804.

18 Wallace RL, Herrick CN: Amniocentesis in the evaluation of premature labor. Obstet Gynecol 1981;57:483-486.

19 Bobitt JR, Hayslip CC, Damato JD: Amniotic fluid infection as determined by transabdominal amniocentesis in patients with intact membranes in premature labor. Am J Obstet Gynecol 1981;140:947-952.

20 Wahbeh CJ, Hill GB, Eden RD, Gall SA: Intra-amniotic bacterial colonization in premature labor. Am J Obstet Gynecol 1984;148:739-743.

21 Romero R, Mazor M: Infection and preterm labor. Clin Obstet Gynecol 1988;31:553-584.

22 Romero R, Sirtori M, Oyarzun E, Avila C, Mazor M, Callahan R, Sabo V, Athanassiadis AP, Hobbins JC: Infection and labor. V. Prevalence, microbiology, and clinical significance of intraamniotic infection in women with preterm labor and intact membranes. Am J Obstet Gynecol 1989;161:817-824.

23 Romero R, Avila C, Brekus CA, Morotti R: The role of systemic and intrauterine infection in preterm parturition. Ann N Y Acad Sci 1991;622:355-375.

24 Watts DH, Krohn MA, Hillier SL, Eschenbach DA: The association of occult amniotic fluid infection with gestational age and neonatal outcome among women in preterm labor. Obstet Gynecol 1992;79:351-357.

25 Yoon BH, Romero R, Moon JB, Oh SY, Han SY, Kim JC, Shim SS: The frequency and clinical significance of intra-amniotic inflammation in patients with a positive cervical fetal fibronectin. Am J Obstet Gynecol 2001;185:1137-1142.

26 Yoon BH, Romero R, Moon JB, Shim SS, Kim M, Kim G, Jun JK: Clinical significance of intra-amniotic inflammation in patients with preterm labor and intact membranes. Am J Obstet Gynecol 2001;185:1130-1136.

27 Romero R, Espinoza J, Chaiworapongsa T, Kalache K: Infection and prematurity and the role of preventive strategies. Semin Neonatol 2002;7:259-274. 
28 Shim SS, Romero R, Hong JS, Park CW, Jun JK, Kim BI, Yoon BH: Clinical significance of intra-amniotic inflammation in patients with preterm premature rupture of membranes. Am J Obstet Gynecol 2004;191:1339-1345.

29 Lee SE, Romero R, Park CW, Jun JK, Yoon BH: The frequency and significance of intraamniotic inflammation in patients with cervical insufficiency. Am J Obstet Gynecol 2008;198:633 e631-638.

30 Lee SE, Romero R, Lee SM, Yoon BH: Amniotic fluid volume in intra-amniotic inflammation with and without culture-proven amniotic fluid infection in preterm premature rupture of membranes. J Perinat Med 2010;38:39-44.

31 Kim SM, Romero R, Lee J, Mi Lee S, Park CW, Shin Park J, Yoon BH: The frequency and clinical significance of intra-amniotic inflammation in women with preterm uterine contractility but without cervical change: do the diagnostic criteria for preterm labor need to be changed? J Matern Fetal Neonatal Med 2012;25:1212-1221.

32 Romero R, Miranda J, Chaiworapongsa T, Chaemsaithong P, Gotsch F, Dong Z, Ahmed AI, Yoon BH, Hassan SS, Kim CJ, Korzeniewski SJ, Yeo L: A novel molecular microbiologic technique for the rapid diagnosis of microbial invasion of the amniotic cavity and intra-amniotic infection in preterm labor with intact membranes. Am J Reprod Immunol 2014;71:330-358.

33 Pacora P, Romero R, Erez O, Maymon E, Panaitescu B, Kusanovic JP, Tarca $A L$, Hsu CD, Hassan SS: The diagnostic performance of the beta-glucan assay in the detection of intra-amniotic infection with Candida species. J Matern Fetal Neonatal Med 2017:1-18.

34 Romero R, Miranda J, Chaiworapongsa T, Chaemsaithong P, Gotsch F, Dong Z, Ahmed Al, Yoon BH, Hassan SS, Kim CJ, Korzeniewski SJ, Yeo L, Kim YM: Sterile intra-amniotic inflammation in asymptomatic patients with a sonographic short cervix: prevalence and clinical significance. J Matern Fetal Neonatal Med 2014:1-17.

35 Romero R, Miranda J, Chaiworapongsa T, Korzeniewski SJ, Chaemsaithong P, Gotsch F, Dong Z, Ahmed Al, Yoon BH, Hassan SS, Kim CJ, Yeo L: Prevalence 
and clinical significance of sterile intra-amniotic inflammation in patients with preterm labor and intact membranes. Am J Reprod Immunol 2014;72:458-474.

36 Romero R, Miranda J, Chaemsaithong P, Chaiworapongsa T, Kusanovic JP, Dong Z, Ahmed Al, Shaman M, Lannaman K, Yoon BH, Hassan SS, Kim CJ, Korzeniewski SJ, Yeo L, Kim YM: Sterile and microbial-associated intra-amniotic inflammation in preterm prelabor rupture of membranes. J Matern Fetal Neonatal Med 2015;28:1394-1409.

37 Oh KJ, Kim SM, Hong JS, Maymon E, Erez O, Panaitescu B, Gomez-Lopez N, Romero R, Yoon BH: Twenty-four percent of patients with clinical chorioamnionitis in preterm gestations have no evidence of either culture-proven intraamniotic infection or intraamniotic inflammation. Am J Obstet Gynecol 2017;216:604 e601-604 e611.

38 Gomez-Lopez N, Romero R, Panaitescu B, Leng Y, Xu Y, Tarca AL, Faro J, Pacora P, Hassan SS, Hsu CD: Inflammasome activation during spontaneous preterm labor with intra-amniotic infection or sterile intra-amniotic inflammation. Am J Reprod Immunol 2018;80:e13049.

39 Romero R, Mazor M, Tartakovsky B: Systemic administration of interleukin-1 induces preterm parturition in mice. Am J Obstet Gynecol 1991;165:969-971.

40 Romero R, Tartakovsky B: The natural interleukin-1 receptor antagonist prevents interleukin-1-induced preterm delivery in mice. Am J Obstet Gynecol 1992;167:1041-1045.

41 Friel LA, Romero R, Edwin S, Nien JK, Gomez R, Chaiworapongsa T, Kusanovic JP, Tolosa JE, Hassan SS, Espinoza J: The calcium binding protein, S100B, is increased in the amniotic fluid of women with intra-amniotic infection/inflammation and preterm labor with intact or ruptured membranes. J Perinat Med 2007;35:385-393.

42 Romero R, Espinoza J, Hassan S, Gotsch F, Kusanovic JP, Avila C, Erez O, Edwin S, Schmidt AM: Soluble receptor for advanced glycation end products (sRAGE) and endogenous secretory RAGE (esRAGE) in amniotic fluid: modulation by infection and inflammation. J Perinat Med 2008;36:388-398. 
43 Chaiworapongsa T, Erez O, Kusanovic JP, Vaisbuch E, Mazaki-Tovi S, Gotsch F, Than NG, Mittal P, Kim YM, Camacho N, Edwin S, Gomez R, Hassan SS, Romero R: Amniotic fluid heat shock protein 70 concentration in histologic chorioamnionitis, term and preterm parturition. J Matern Fetal Neonatal Med 2008;21:449-461.

44 Romero R, Chaiworapongsa T, Alpay Savasan Z, Xu Y, Hussein Y, Dong Z, Kusanovic JP, Kim CJ, Hassan SS: Damage-associated molecular patterns (DAMPS) in preterm labor with intact membranes and preterm PROM: a study of the alarmin HMGB1. J Matern Fetal Neonatal Med 2011;24:1444-1455.

45 Romero R, Chaiworapongsa T, Savasan ZA, Hussein Y, Dong Z, Kusanovic JP, Kim CJ, Hassan SS: Clinical chorioamnionitis is characterized by changes in the expression of the alarmin HMGB1 and one of its receptors, sRAGE. J Matern Fetal Neonatal Med 2012;25:558-567.

46 Romero R, Grivel JC, Tarca AL, Chaemsaithong P, Xu Z, Fitzgerald W, Hassan SS, Chaiworapongsa T, Margolis L: Evidence of perturbations of the cytokine network in preterm labor. Am J Obstet Gynecol 2015;213:836 e831-836 e818.

47 Gomez-Lopez N, Romero R, Plazyo O, Panaitescu B, Furcron AE, Miller D, Roumayah T, Flom E, Hassan SS: Intra-Amniotic Administration of HMGB1 Induces Spontaneous Preterm Labor and Birth. Am J Reprod Immunol 2016;75:3-7.

48 Plazyo O, Romero R, Unkel R, Balancio A, Mial TN, Xu Y, Dong Z, Hassan SS, Gomez-Lopez N: HMGB1 Induces an Inflammatory Response in the Chorioamniotic Membranes That Is Partially Mediated by the Inflammasome. Biol Reprod 2016;95:130.

49 Gomez-Lopez N, Romero R, Plazyo O, Schwenkel G, Garcia-Flores V, Unkel R, Xu Y, Leng Y, Hassan SS, Panaitescu B, Cha J, Dey SK: Preterm labor in the absence of acute histologic chorioamnionitis is characterized by cellular senescence of the chorioamniotic membranes. Am J Obstet Gynecol 2017;217:592 e591-592 e517.

50 Kim YM, Romero R, Chaiworapongsa T, Kim GJ, Kim MR, Kuivaniemi H, Tromp G, Espinoza J, Bujold E, Abrahams VM, Mor G: Toll-like receptor-2 and -4 in the 
chorioamniotic membranes in spontaneous labor at term and in preterm parturition that are associated with chorioamnionitis. Am J Obstet Gynecol 2004;191:1346-1355.

51 Mittal P, Romero R, Kusanovic JP, Edwin SS, Gotsch F, Mazaki-Tovi S, Espinoza J, Erez O, Nhan-Chang CL, Than NG, Vaisbuch E, Hassan SS: CXCL6 (granulocyte chemotactic protein-2): a novel chemokine involved in the innate immune response of the amniotic cavity. Am J Reprod Immunol 2008;60:246257.

52 Gotsch F, Romero R, Chaiworapongsa T, Erez O, Vaisbuch E, Espinoza J, Kusanovic JP, Mittal P, Mazaki-Tovi S, Kim CJ, Kim JS, Edwin S, Nhan-Chang CL, Hamill N, Friel L, Than NG, Mazor M, Yoon BH, Hassan SS: Evidence of the involvement of caspase-1 under physiologic and pathologic cellular stress during human pregnancy: a link between the inflammasome and parturition. J Matern Fetal Neonatal Med 2008;21:605-616.

53 Cardenas I, Means RE, Aldo P, Koga K, Lang SM, Booth CJ, Manzur A, Oyarzun E, Romero R, Mor G: Viral infection of the placenta leads to fetal inflammation and sensitization to bacterial products predisposing to preterm labor. J Immunol 2010;185:1248-1257.

54 Ilievski V, Hirsch E: Synergy between viral and bacterial toll-like receptors leads to amplification of inflammatory responses and preterm labor in the mouse. Biol Reprod 2010;83:767-773.

55 Abrahams VM: The role of the Nod-like receptor family in trophoblast innate immune responses. J Reprod Immunol 2011;88:112-117.

56 Lappas M: NOD1 and NOD2 regulate proinflammatory and prolabor mediators in human fetal membranes and myometrium via nuclear factor-kappa B. Biol Reprod 2013;89:14.

57 Jaiswal MK, Agrawal V, Mallers T, Gilman-Sachs A, Hirsch E, Beaman KD: Regulation of apoptosis and innate immune stimuli in inflammation-induced preterm labor. J Immunol 2013;191:5702-5713. 
58 Koga K, Izumi G, Mor G, Fujii T, Osuga Y: Toll-like receptors at the maternal-fetal interface in normal pregnancy and pregnancy complications. Am J Reprod Immunol 2014;72:192-205.

59 Agrawal V, Jaiswal MK, llievski V, Beaman KD, Jilling T, Hirsch E: Plateletactivating factor: a role in preterm delivery and an essential interaction with Tolllike receptor signaling in mice. Biol Reprod 2014;91:119.

60 St Louis D, Romero R, Plazyo O, Arenas-Hernandez M, Panaitescu B, Xu Y, Milovic T, Xu Z, Bhatti G, Mi QS, Drewlo S, Tarca AL, Hassan SS, Gomez-Lopez $\mathrm{N}$ : Invariant NKT Cell Activation Induces Late Preterm Birth That Is Attenuated by Rosiglitazone. J Immunol 2016;196:1044-1059.

61 Xu Y, Romero R, Miller D, Kadam L, Mial TN, Plazyo O, Garcia-Flores V, Hassan SS, Xu Z, Tarca AL, Drewlo S, Gomez-Lopez N: An M1-like Macrophage Polarization in Decidual Tissue during Spontaneous Preterm Labor That Is Attenuated by Rosiglitazone Treatment. J Immunol 2016;196:2476-2491.

62 Arenas-Hernandez M, Romero R, St Louis D, Hassan SS, Kaye EB, GomezLopez N: An imbalance between innate and adaptive immune cells at the maternal-fetal interface occurs prior to endotoxin-induced preterm birth. Cell Mol Immunol 2016;13:462-473.

63 Gomez-Lopez N, Romero R, Leng Y, Garcia-Flores V, Xu Y, Miller D, Hassan SS: Neutrophil extracellular traps in acute chorioamnionitis: A mechanism of host defense. Am J Reprod Immunol 2017;77.

64 Negishi Y, Shima Y, Takeshita T, Takahashi H: Distribution of invariant natural killer T cells and dendritic cells in late pre-term birth without acute chorioamnionitis. Am J Reprod Immunol 2017;77.

65 Gomez-Lopez N, Romero R, Xu Y, Miller D, Unkel R, Shaman M, Jacques SM, Panaitescu B, Garcia-Flores V, Hassan SS: Neutrophil Extracellular Traps in the Amniotic Cavity of Women with Intra-Amniotic Infection: A New Mechanism of Host Defense. Reprod Sci 2017;24:1139-1153.

66 Gomez-Lopez N, Romero R, Xu Y, Plazyo O, Unkel R, Leng Y, Than NG, Chaiworapongsa T, Panaitescu B, Dong Z, Tarca AL, Abrahams VM, Yeo L, 
Hassan SS: A Role for the Inflammasome in Spontaneous Preterm Labor With Acute Histologic Chorioamnionitis. Reprod Sci 2017;24:1382-1401.

67 Gomez-Lopez N, Romero R, Garcia-Flores V, Xu Y, Leng Y, Alhousseini A, Hassan SS, Panaitescu B: Amniotic fluid neutrophils can phagocytize bacteria: A mechanism for microbial killing in the amniotic cavity. Am J Reprod Immunol 2017;78.

68 Musilova I, Andrys C, Krejsek J, Drahosova M, Zednikova B, Pliskova L, Zemlickova H, Jacobsson B, Kacerovsky M: Amniotic fluid pentraxins: Potential early markers for identifying intra-amniotic inflammatory complications in preterm pre-labor rupture of membranes. Am J Reprod Immunol 2017.

69 Gomez-Lopez N, Romero R, Xu Y, Leng Y, Garcia-Flores V, Miller D, Jacques SM, Hassan SS, Faro J, Alsamsam A, Alhousseini A, Gomez-Roberts H, Panaitescu B, Yeo L, Maymon E: Are amniotic fluid neutrophils in women with intraamniotic infection and/or inflammation of fetal or maternal origin? Am J Obstet Gynecol 2017;217:693 e691-693 e616.

$70 \mathrm{Xu}$ Y, Romero R, Miller D, Silva P, Panaitescu B, Theis KR, Arif A, Hassan SS, Gomez-Lopez N: Innate lymphoid cells at the human maternal-fetal interface in spontaneous preterm labor. Am J Reprod Immunol 2018;79:e12820.

71 Varrey A, Romero R, Panaitescu B, Miller D, Chaiworapongsa T, Patwardhan M, Faro J, Pacora P, Hassan SS, Hsu CD, Gomez-Lopez N: Human beta-defensin1: A natural antimicrobial peptide present in amniotic fluid that is increased in spontaneous preterm labor with intra-amniotic infection. Am J Reprod Immunol 2018;80:e13031.

72 Paquette AG, Shynlova O, Kibschull M, Price ND, Lye SJ, Global Alliance to Prevent P, Stillbirth Systems Biology of Preterm Birth T: Comparative analysis of gene expression in maternal peripheral blood and monocytes during spontaneous preterm labor. Am J Obstet Gynecol 2018;218:345 e341-345 e330.

73 Miller D, Motomura K, Garcia-Flores V, Romero R, Gomez-Lopez N: Innate Lymphoid Cells in the Maternal and Fetal Compartments. Front Immunol 2018;9:2396. 
74 Vargas ML, Santos JL, Ruiz C, Montes MJ, Aleman P, Garcia-Tortosa C, GarciaOlivares $\mathrm{E}$ : Comparison of the proportions of leukocytes in early and term human decidua. Am J Reprod Immunol 1993;29:135-140.

75 Bonney EA, Pudney J, Anderson DJ, Hill JA: Gamma-delta T cells in midgestation human placental villi. Gynecol Obstet Invest 2000;50:153-157.

76 Sindram-Trujillo A, Scherjon S, Kanhai H, Roelen D, Claas F: Increased T-cell activation in decidua parietalis compared to decidua basalis in uncomplicated human term pregnancy. Am J Reprod Immunol 2003;49:261-268.

77 Sindram-Trujillo AP, Scherjon SA, van Hulst-van Miert PP, Kanhai HH, Roelen $\mathrm{DL}$, Claas FH: Comparison of decidual leukocytes following spontaneous vaginal delivery and elective cesarean section in uncomplicated human term pregnancy. J Reprod Immunol 2004;62:125-137.

78 Tilburgs T, Roelen DL, van der Mast BJ, van Schip JJ, Kleijburg C, de GrootSwings GM, Kanhai HH, Claas FH, Scherjon SA: Differential distribution of CD4(+)CD25(bright) and CD8(+)CD28(-) T-cells in decidua and maternal blood during human pregnancy. Placenta 2006;27 Suppl A:S47-53.

79 Constantin CM, Masopust D, Gourley T, Grayson J, Strickland OL, Ahmed R, Bonney EA: Normal establishment of virus-specific memory CD8 T cell pool following primary infection during pregnancy. J Immunol 2007;179:4383-4389.

80 Tilburgs T, Scherjon SA, Roelen DL, Claas FH: Decidual CD8+CD28- T cells express CD103 but not perforin. Hum Immunol 2009;70:96-100.

81 Tilburgs T, van der Mast BJ, Nagtzaam NM, Roelen DL, Scherjon SA, Claas FH: Expression of NK cell receptors on decidual T cells in human pregnancy. $\mathrm{J}$ Reprod Immunol 2009;80:22-32.

82 Norton MT, Fortner KA, Oppenheimer KH, Bonney EA: Evidence that CD8 T-cell homeostasis and function remain intact during murine pregnancy. Immunology 2010;131:426-437.

83 Tilburgs T, Schonkeren D, Eikmans M, Nagtzaam NM, Datema G, Swings GM, Prins F, van Lith JM, van der Mast BJ, Roelen DL, Scherjon SA, Claas FH: Human decidual tissue contains differentiated CD8+ effector-memory $T$ cells with unique properties. J Immunol 2010;185:4470-4477. 
84 Gomez-Lopez N, Vadillo-Perez L, Hernandez-Carbajal A, Godines-Enriquez M, Olson DM, Vadillo-Ortega F: Specific inflammatory microenvironments in the zones of the fetal membranes at term delivery. Am J Obstet Gynecol 2011;205:235 e215-224.

85 Gomez-Lopez N, Vega-Sanchez R, Castillo-Castrejon M, Romero R, CubeiroArreola K, Vadillo-Ortega F: Evidence for a role for the adaptive immune response in human term parturition. Am J Reprod Immunol 2013;69:212-230.

86 Shepard MT, Bonney EA: PD-1 regulates T cell proliferation in a tissue and subset-specific manner during normal mouse pregnancy. Immunol Invest 2013;42:385-408.

87 Bonney EA: Alternative theories: Pregnancy and immune tolerance. J Reprod Immunol 2017;123:65-71.

88 Powell RM, Lissauer D, Tamblyn J, Beggs A, Cox P, Moss P, Kilby MD: Decidual T Cells Exhibit a Highly Differentiated Phenotype and Demonstrate Potential Fetal Specificity and a Strong Transcriptional Response to IFN. J Immunol 2017;199:3406-3417.

89 van der Zwan A, Bi K, Norwitz ER, Crespo AC, Claas FHJ, Strominger JL, Tilburgs T: Mixed signature of activation and dysfunction allows human decidual CD8(+) T cells to provide both tolerance and immunity. Proc Natl Acad Sci U S A 2018;115:385-390.

90 Kim CJ, Romero R, Kusanovic JP, Yoo W, Dong Z, Topping V, Gotsch F, Yoon

$\mathrm{BH}, \mathrm{Chi}$ JG, Kim JS: The frequency, clinical significance, and pathological features of chronic chorioamnionitis: a lesion associated with spontaneous preterm birth. Mod Pathol 2010;23:1000-1011.

91 Lee J, Romero R, Xu Y, Kim JS, Topping V, Yoo W, Kusanovic JP, Chaiworapongsa T, Hassan SS, Yoon BH, Kim CJ: A signature of maternal antifetal rejection in spontaneous preterm birth: chronic chorioamnionitis, anti-human leukocyte antigen antibodies, and C4d. PLoS One 2011;6:e16806.

92 Xu Y, Tarquini F, Romero R, Kim CJ, Tarca AL, Bhatti G, Lee J, Sundell IB, Mittal P, Kusanovic JP, Hassan SS, Kim JS: Peripheral CD300a+CD8+ T lymphocytes 
with a distinct cytotoxic molecular signature increase in pregnant women with chronic chorioamnionitis. Am J Reprod Immunol 2012;67:184-197.

93 Lee J, Kim JS, Park JW, Park CW, Park JS, Jun JK, Yoon BH: Chronic chorioamnionitis is the most common placental lesion in late preterm birth. Placenta 2013;34:681-689.

94 Kim CJ, Romero R, Chaemsaithong P, Kim JS: Chronic inflammation of the placenta: definition, classification, pathogenesis, and clinical significance. Am J Obstet Gynecol 2015;213:S53-69.

95 Gomez-Lopez N, Romero R, Arenas-Hernandez M, Ahn H, Panaitescu B, Vadillo-Ortega F, Sanchez-Torres C, Salisbury KS, Hassan SS: In vivo T-cell activation by a monoclonal alphaCD3epsilon antibody induces preterm labor and birth. Am J Reprod Immunol 2016;76:386-390.

96 Frascoli M, Coniglio L, Witt R, Jeanty C, Fleck-Derderian S, Myers DE, Lee TH, Keating S, Busch MP, Norris PJ, Tang Q, Cruz G, Barcellos LF, Gomez-Lopez N, Romero R, MacKenzie TC: Alloreactive fetal T cells promote uterine contractility in preterm labor via IFN-gamma and TNF-alpha. Sci TransI Med 2018;10.

97 Arenas-Hernandez M, Romero R, Xu Y, Panaitescu B, Garcia-Flores V, Ahn H, Done B, Hassan S, Hsu CD, Sanchez-Torres C, Gomez-Lopez N: Effector and activated T cells Induce Preterm Labor and Birth that is Prevented by Treatment with Progesterone. J Immunol 2018:Submitted.

98 Bulmer JN, Sunderland CA: Immunohistological characterization of lymphoid cell populations in the early human placental bed. Immunology 1984;52:349-357.

99 Haller H, Radillo O, Rukavina D, Tedesco F, Candussi G, Petrovic O, Randic L: An immunohistochemical study of leucocytes in human endometrium, first and third trimester basal decidua. J Reprod Immunol 1993;23:41-49.

100 Bartmann C, Segerer SE, Rieger L, Kapp M, Sutterlin M, Kammerer U: Quantification of the predominant immune cell populations in decidua throughout human pregnancy. Am J Reprod Immunol 2014;71:109-119.

101 Redline RW, Lu CY: Localization of fetal major histocompatibility complex antigens and maternal leukocytes in murine placenta. Implications for maternalfetal immunological relationship. Lab Invest 1989;61:27-36. 
102 Jensen F, Muzzio D, Soldati R, Fest S, Zenclussen AC: Regulatory B10 cells restore pregnancy tolerance in a mouse model. Biol Reprod 2013;89:90.

103 Muzzio D, Zenclussen AC, Jensen F: The role of $B$ cells in pregnancy: the good and the bad. Am J Reprod Immunol 2013;69:408-412.

104 Rolle L, Memarzadeh Tehran M, Morell-Garcia A, Raeva Y, Schumacher A, Hartig R, Costa SD, Jensen F, Zenclussen AC: Cutting edge: IL-10-producing regulatory $B$ cells in early human pregnancy. Am J Reprod Immunol 2013;70:448-453.

105 Zenclussen AC: Adaptive immune responses during pregnancy. Am J Reprod Immunol 2013;69:291-303.

106 Fettke F, Schumacher A, Costa SD, Zenclussen AC: B cells: the old new players in reproductive immunology. Front Immunol 2014;5:285.

107 Muzzio D, Zygmunt M, Jensen F: The role of pregnancy-associated hormones in the development and function of regulatory B cells. Front Endocrinol (Lausanne) 2014;5:39.

108 Muzzio DO, Soldati R, Ehrhardt J, Utpatel K, Evert M, Zenclussen AC, Zygmunt $M$, Jensen $F$ : B cell development undergoes profound modifications and adaptations during pregnancy in mice. Biol Reprod 2014;91:115.

109 Muzzio DO, Soldati R, Rolle L, Zygmunt M, Zenclussen AC, Jensen F: B-1a B cells regulate $T$ cell differentiation associated with pregnancy disturbances. Front Immunol 2014;5:6.

110 Bommer I, Muzzio DO, Zygmunt M, Jensen F: Progesterone and estradiol exert an inhibitory effect on the production of anti-inflammatory cytokine IL-10 by activated MZ B cells. J Reprod Immunol 2016;116:113-116.

111 Fettke F, Schumacher A, Canellada A, Toledo N, Bekeredjian-Ding I, Bondt A, Wuhrer M, Costa SD, Zenclussen AC: Maternal and Fetal Mechanisms of B Cell Regulation during Pregnancy: Human Chorionic Gonadotropin Stimulates B Cells to Produce IL-10 While Alpha-Fetoprotein Drives Them into Apoptosis. Front Immunol 2016;7:495. 
112 Muzzio DO, Ziegler KB, Ehrhardt J, Zygmunt M, Jensen F: Marginal zone B cells emerge as a critical component of pregnancy well-being. Reproduction 2016;151:29-37.

113 Wolfson ML, Muzzio DO, Ehrhardt J, Franchi AM, Zygmunt M, Jensen F: Expression analysis of cannabinoid receptors 1 and 2 in B cells during pregnancy and their role on cytokine production. J Reprod Immunol 2016;116:23-27.

114 Schumacher A, Ehrentraut S, Scharm M, Wang H, Hartig R, Morse HC, 3rd, Zenclussen AC: Plasma Cell Alloantigen 1 and IL-10 Secretion Define Two Distinct Peritoneal B1a B Cell Subsets With Opposite Functions, PC1(high) Cells Being Protective and PC1(low) Cells Harmful for the Growing Fetus. Front Immunol 2018;9:1045.

115 Ziegler KB, Muzzio DO, Matzner F, Bommer I, Ventimiglia MS, Malinowsky K, Ehrhardt J, Zygmunt M, Jensen F: Human pregnancy is accompanied by modifications in B cell development and immunoglobulin profile. J Reprod Immunol 2018;129:40-47.

116 Rinaldi SF, Makieva S, Saunders PT, Rossi AG, Norman JE: Immune cell and transcriptomic analysis of the human decidua in term and preterm parturition. Mol Hum Reprod 2017;23:708-724.

117 Solders M, Gorchs L, Gidlof S, Tiblad E, Lundell AC, Kaipe H: Maternal Adaptive Immune Cells in Decidua Parietalis Display a More Activated and Coinhibitory Phenotype Compared to Decidua Basalis. Stem Cells Int 2017;2017:8010961.

118 Huang B, Faucette AN, Pawlitz MD, Pei B, Goyert JW, Zhou JZ, El-Hage NG, Deng J, Lin J, Yao F, Dewar RS, 3rd, Jassal JS, Sandberg ML, Dai J, Cols M, Shen C, Polin LA, Nichols RA, Jones TB, Bluth MH, Puder KS, Gonik B, Nayak NR, Puscheck E, Wei WZ, Cerutti A, Colonna M, Chen K: Interleukin-33-induced expression of PIBF1 by decidual $B$ cells protects against preterm labor. Nat Med 2017:23:128-135.

119 Redline RW, Faye-Petersen O, Heller D, Qureshi F, Savell V, Vogler C, Society for Pediatric Pathology PSAFINC: Amniotic infection syndrome: nosology and reproducibility of placental reaction patterns. Pediatr Dev Pathol 2003;6:435-448. 
120 Redline RW: Inflammatory responses in the placenta and umbilical cord. Semin Fetal Neonatal Med 2006;11:296-301.

121 Kim CJ, Romero R, Chaemsaithong P, Chaiyasit N, Yoon BH, Kim YM: Acute chorioamnionitis and funisitis: definition, pathologic features, and clinical significance. Am J Obstet Gynecol 2015;213:S29-52.

122 Redline RW: Classification of placental lesions. Am J Obstet Gynecol 2015;213:S21-28.

123 Xu Y, Plazyo O, Romero R, Hassan SS, Gomez-Lopez N: Isolation of Leukocytes from the Human Maternal-fetal Interface. J Vis Exp 2015:e52863.

124 Montecino-Rodriguez E, Dorshkind K: B-1 B cell development in the fetus and adult. Immunity 2012;36:13-21.

125 Chung JB, Silverman M, Monroe JG: Transitional B cells: step by step towards immune competence. Trends Immunol 2003;24:343-349.

126 Palanichamy A, Barnard J, Zheng B, Owen T, Quach T, Wei C, Looney RJ, Sanz I, Anolik JH: Novel human transitional B cell populations revealed by $\mathrm{B}$ cell depletion therapy. J Immunol 2009;182:5982-5993.

127 Carsetti R, Kohler G, Lamers MC: Transitional B cells are the target of negative selection in the B cell compartment. J Exp Med 1995;181:2129-2140.

128 Loder F, Mutschler B, Ray RJ, Paige CJ, Sideras P, Torres R, Lamers MC, Carsetti R: B cell development in the spleen takes place in discrete steps and is determined by the quality of $B$ cell receptor-derived signals. J Exp Med 1999;190:75-89.

129 Weisel F, Shlomchik M: Memory B Cells of Mice and Humans. Annu Rev Immunol 2017;35:255-284.

130 Seifert M, Kuppers R: Human memory B cells. Leukemia 2016;30:2283-2292.

131 Lund FE: Cytokine-producing $B$ lymphocytes-key regulators of immunity. Curr Opin Immunol 2008;20:332-338.

132 Shen P, Fillatreau S: Antibody-independent functions of B cells: a focus on cytokines. Nat Rev Immunol 2015;15:441-451. 
133 Griffin DO, Holodick NE, Rothstein TL: Human B1 cells in umbilical cord and adult peripheral blood express the novel phenotype CD20+ CD27+ CD43+ CD70. J Exp Med 2011;208:67-80.

134 Shresta S, Pham CT, Thomas DA, Graubert TA, Ley TJ: How do cytotoxic lymphocytes kill their targets? Curr Opin Immunol 1998;10:581-587.

135 Trapani JA, Smyth MJ: Functional significance of the perforin/granzyme cell death pathway. Nat Rev Immunol 2002;2:735-747.

136 Trambas CM, Griffiths GM: Delivering the kiss of death. Nat Immunol 2003;4:399-403.

137 Grossman WJ, Verbsky JW, Tollefsen BL, Kemper C, Atkinson JP, Ley TJ: Differential expression of granzymes $A$ and $B$ in human cytotoxic lymphocyte subsets and T regulatory cells. Blood 2004;104:2840-2848.

138 Rock MT, Yoder SM, Wright PF, Talbot TR, Edwards KM, Crowe JE, Jr.: Differential regulation of granzyme and perforin in effector and memory $T$ cells following smallpox immunization. J Immunol 2005;174:3757-3764.

139 Takata H, Takiguchi M: Three memory subsets of human CD8+ T cells differently expressing three cytolytic effector molecules. J Immunol 2006;177:4330-4340.

140 Lin L, Couturier J, Yu X, Medina MA, Kozinetz CA, Lewis DE: Granzyme B secretion by human memory CD4 T cells is less strictly regulated compared to memory CD8 T cells. BMC Immunol 2014;15:36.

141 Alhakeem SS, Sindhava VJ, McKenna MK, Gachuki BW, Byrd JC, Muthusamy $\mathrm{N}$, Bondada S: Role of B cell receptor signaling in IL-10 production by normal and malignant B-1 cells. Ann N Y Acad Sci 2015;1362:239-249.

142 Moens L, Kane A, Tangye SG: Naive and memory B cells exhibit distinct biochemical responses following BCR engagement. Immunol Cell Biol 2016;94:774-786.

143 Jelinek DF, Splawski JB, Lipsky PE: Human peripheral blood B lymphocyte subpopulations: functional and phenotypic analysis of surface $\lg D$ positive and negative subsets. J Immunol 1986;136:83-92.

144 Liu YJ, Barthelemy C, de Bouteiller O, Arpin C, Durand I, Banchereau J: Memory B cells from human tonsils colonize mucosal epithelium and directly present 
antigen to T cells by rapid up-regulation of B7-1 and B7-2. Immunity 1995;2:239248.

145 Tangye SG, Tarlinton DM: Memory B cells: effectors of long-lived immune responses. Eur J Immunol 2009;39:2065-2075.

146 Claes N, Fraussen J, Stinissen P, Hupperts R, Somers V: B Cells Are Multifunctional Players in Multiple Sclerosis Pathogenesis: Insights from Therapeutic Interventions. Front Immunol 2015;6:642.

147 Halliley JL, Tipton CM, Liesveld J, Rosenberg AF, Darce J, Gregoretti IV, Popova L, Kaminiski D, Fucile CF, Albizua I, Kyu S, Chiang KY, Bradley KT, Burack R, Slifka M, Hammarlund E, Wu H, Zhao L, Walsh EE, Falsey AR, Randall TD, Cheung WC, Sanz I, Lee FE: Long-Lived Plasma Cells Are Contained within the CD19(-)CD38(hi)CD138(+) Subset in Human Bone Marrow. Immunity 2015;43:132-145.

148 Landsverk OJ, Snir O, Casado RB, Richter L, Mold JE, Reu P, Horneland R, Paulsen V, Yaqub S, Aandahl EM, Oyen OM, Thorarensen HS, Salehpour M, Possnert G, Frisen J, Sollid LM, Baekkevold ES, Jahnsen FL: Antibody-secreting plasma cells persist for decades in human intestine. J Exp Med 2017;214:309-

\section{7.}

149 Leandro MJ: B-cell subpopulations in humans and their differential susceptibility to depletion with anti-CD20 monoclonal antibodies. Arthritis Res Ther 2013;15 Suppl 1:S3.

150 De Silva NS, Klein U: Dynamics of B cells in germinal centres. Nat Rev Immunol 2015;15:137-148.

151 Klein U, Dalla-Favera R: Germinal centres: role in B-cell physiology and malignancy. Nat Rev Immunol 2008;8:22-33.

152 Prins JR, Gomez-Lopez N, Robertson SA: Interleukin-6 in pregnancy and gestational disorders. J Reprod Immunol 2012;95:1-14.

153 Mao H, Gao W, Ma C, Sun J, Liu J, Shao Q, Song B, Qu X: Human placental trophoblasts express the immunosuppressive cytokine IL-35. Hum Immunol 2013;74:872-877. 


\section{FIGURE LEGENDS}

Figure 1. Immunophenotyping of $B$ cells in the decidua basalis and decidua parietalis. (A) Representation of the spatial localization of the decidua basalis and decidua parietalis. (B) Flow cytometry gating strategy used to identify B cells in the decidual tissues. Lymphocytes were gated using forward scatter (FSC) versus side scatter (SSC). B cells were gated as $\mathrm{CD}^{-} 19^{+} \mathrm{CD}^{-}$cells within the viability and lymphocytic gates. (C) The proportion of $\mathrm{CD} 19^{+} \mathrm{B}$ cells in samples of case-matched decidua basalis, decidua parietalis, maternal blood, and cord blood $(n=5)$. (D) Coexpression of $\mathrm{CD} 20$ by $\mathrm{CD} 19^{+} \mathrm{B}$ cells in the decidua basalis, decidua parietalis, maternal blood, and cord blood. The proportions of CD19 $\mathrm{B}$ cells in the decidua basalis (E) or decidua parietalis (G) from women who delivered at term with labor (TIL) or without labor (TNL) and women who delivered preterm with labor (PTL) or without labor (PTNL). $\mathrm{N}=6-37$ per group. The TIL and PTL patients were subdivided into those with acute histologic chorioamnionitis (ACA) or chronic histologic chorioamnionitis (CCA), and those without these lesions. Non-labor controls without ACA or CCA were included as well. The proportions of $C D 19^{+} B$ cells in the decidua basalis $(F)$ or decidua parietalis (H) in these patient subgroups. $\mathrm{N}=4-16$ per group. Red midlines and whiskers indicate medians and interquartile ranges, respectively.

Figure 2. B-cell subsets in the decidua basalis and decidua parietalis. (A) Schematic representation of B1 and B2 B cells. (B) Schematic representation of the Bcell subsets identified in the decidual tissues. (C) Flow cytometry gating strategy used to identify the following B-cell subsets: $\mathrm{B} 1 \mathrm{~B}$ cells $\left(\mathrm{CD} 3^{-} \mathrm{CD} 19^{+} \mathrm{CD} 2 \mathrm{O}^{+} \mathrm{CD} 27^{+} \mathrm{CD} 43^{+}\right.$cells); transitional $B$ cells $\left(C D 3^{-} C D 19^{+} C D 20^{+} C D 38^{\text {hi }} C D 24^{\text {hi }}\right.$ cells); naïve B cells (CD3 ${ }^{-}$ $\mathrm{CD}_{19^{+} \mathrm{CD} 20^{+} \mathrm{CD} 27^{-} \mathrm{lgD}{ }^{+}}$cells); class-switched memory $\mathrm{B}$ cells (CD3 ${ }^{-}$

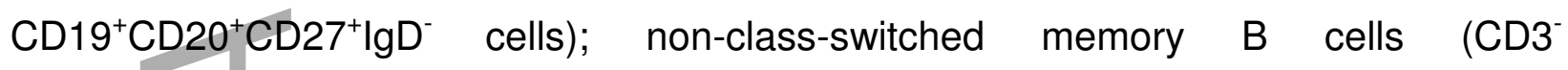
$\mathrm{CD} 19^{+} \mathrm{CD} 20^{+} \mathrm{CD} 27^{+} \mathrm{IgD}{ }^{+}$cells); and plasmablasts (CD3 ${ }^{-} \mathrm{CD} 19^{+} \mathrm{CD} 20^{-} \mathrm{CD} 38^{+} \mathrm{CD} 24^{-}$cells).

(D) A representative t-distributed stochastic neighbor embedding ( $\mathrm{t}-\mathrm{SNE}$ ) dot plot visualizing $B$-cell subsets in the decidual tissues. Red $=B 1 \mathrm{~B}$ cells, purple $=$ transitional $B$ cells, orange $=$ naïve $B$ cells, blue $=$ class-switched memory $B$ cells, green $=$ non- 
class-switched memory B cells, turquoise $=$ plasmablasts, and grey $=$ other $\mathrm{CD} 19^{+} \mathrm{B}$ cells.

Figure 3. B1, B cells in the decidua basalis and decidua parietalis. (A) A representative $t$-distributed stochastic neighbor embedding ( $t-S N E)$ dot plot visualizing B1 B cells in the decidual tissues. Red $=$ B1 B cells and grey $=$ other CD19 $B$ cells. The proportions of $B 1 B$ cells in the decidua basalis (B) or decidua parietalis (D) from women who delivered at term with labor (TIL) or without labor (TNL) and women who delivered preterm with labor (PTL) or without labor (PTNL). $N=6-37$ per group. The TIL and PTL patients were subdivided into those with acute histologic chorioamnionitis (ACA) or chronic histologic chorioamnionitis (CCA), and those without these lesions. Non-labor controls without ACA or CCA were included as well. The proportions of B1 B cells in the decidua basalis (C) or decidua parietalis (E) in these patient subgroups. $N=$ 4-16 pergroup. Red midlines and whiskers indicate medians and interquartile ranges, respectively.

Figure 4. Transitional $B$ cells in the decidua basalis and decidua parietalis. (A) A representative $t$-distributed stochastic neighbor embedding ( $t-S N E)$ dot plot visualizing transitional $B$ cells in the decidual tissues. Red $=$ transitional B cells and grey $=$ other CD19+ $\mathrm{B}$ cells. The proportions of transitional B cells in the decidua basalis (B) or decidua parietalis (D) from women who delivered at term with labor (TIL) or without labor (TNL) and women who delivered preterm with labor (PTL) or without labor (PTNL). $\mathrm{N}=6-37$ per group. The TIL and PTL patients were subdivided into those with acute histologic chorioamnionitis (ACA) or chronic histologic chorioamnionitis (CCA), and those without these lesions. Non-labor controls without ACA or CCA were included as well. The proportions of transitional $B$ cells in the decidua basalis (C) or decidua parietalis (E) in these patient subgroups. $N=4-16$ per group. Red midlines and whiskers indicate medians and interquartile ranges, respectively.

Figure 5. Naïve B cells in the decidua basalis and decidua parietalis. (A) A representative t-distributed stochastic neighbor embedding (t-SNE) dot plot visualizing 
naïve $B$ cells in the decidual tissues. Red $=$ naïve $B$ cells and grey $=$ other CD19+ $B$ cells. The proportions of naïve $B$ cells in the decidua basalis (B) or decidua parietalis (D) from women who delivered at term with labor (TIL) or without labor (TNL) and women who delivered preterm with labor (PTL) or without labor (PTNL). N = 6-37 per group. The TIL and PTL patients were subdivided into those with acute histologic chorioamnionitis (ACA) or chronic histologic chorioamnionitis (CCA), and those without these lesions. Non-labor controls without ACA or CCA were included as well. The proportions of naïve B cells in the decidua basalis (C) or decidua parietalis (E) in these patient subgroups. $\mathrm{N}=4-16$ per group. Red midlines and whiskers indicate medians and interquartile ranges, respectively.

Figure 6. Class-switched memory $B$ cells in the decidua basalis and decidua parietalis. (A) A representative t-distributed stochastic neighbor embedding (t-SNE) dot plot visualizing class-switched memory $B$ cells in the decidual tissues. Red = classswitched memory B cells and grey $=$ other $\mathrm{CD} 19^{+} \mathrm{B}$ cells. The proportions of classswitched memory B cells in the decidua basalis (B) or decidua parietalis (D) from women who delivered at term with labor (TIL) or without labor (TNL) and women who delivered preterm with labor (PTL) or without labor (PTNL). N =6-37 per group. The TIL and PTL patients were subdivided into those with acute histologic chorioamnionitis (ACA) or chronic histologic chorioamnionitis (CCA), and those without these lesions. Non-labor controls without ACA or CCA were included as well. The proportions of classswitched memory B cells in the decidua basalis (C) or decidua parietalis (E) in these patient subgroups. $\mathrm{N}=4-16$ per group. Red midlines and whiskers indicate medians and interquartile ranges, respectively.

Figure 7. Non-class-switched memory $B$ cells in the decidua basalis and decidua parietalis. (A) A representative $t$-distributed stochastic neighbor embedding (t-SNE) dot plot visualizing non-class-switched memory $B$ cells in the decidual tissues. Red = nonclass-switched memory B cells and grey $=$ other $\mathrm{CD} 19^{+} \mathrm{B}$ cells. The proportions of nonclass-switched memory B cells in the decidua basalis (B) or decidua parietalis (D) from women who delivered at term with labor (TIL) or without labor (TNL) and women who 
delivered preterm with labor (PTL) or without labor (PTNL). $N=6-37$ per group. The TIL and PTL patients were subdivided into those with acute histologic chorioamnionitis (ACA) or chronic histologic chorioamnionitis (CCA), and those without these lesions. Non-labor controls without ACA or CCA were included as well. The proportions of nonclass-switched memory B cells in the decidua basalis (C) or decidua parietalis (E) in these patient subgroups. $\mathrm{N}=4-16$ per group. Red midlines and whiskers indicate medians and interquartile ranges, respectively.

Figure 8. Plasmablasts in the decidua basalis and decidua parietalis. (A) A representative $t$-distributed stochastic neighbor embedding (t-SNE) dot plot visualizing plasmablasts in the decidual tissues. Red $=$ plasmablasts, blue $=\mathrm{CD} 19^{+} \mathrm{CD} 20^{-} \mathrm{B}$ cells, and grey $=$ other $\mathrm{CD} 19^{+} \mathrm{B}$ cells. The proportions of plasmablasts in the decidua basalis (B) or decidua parietalis (D) from women who delivered at term with labor (TIL) or without labor (TNL) and women who delivered preterm with labor (PTL) or without labor (PTNL). $\mathrm{N}=6-37$ per group. The TIL and PTL patients were subdivided into those with acute histologic chorioamnionitis (ACA) or chronic histologic chorioamnionitis (CCA), and those without these lesions. Non-labor controls without ACA or CCA were included as well. The proportions of plasmablasts in the decidua basalis (C) or decidua parietalis (E) in these patient subgroups. $\mathrm{N}=4-16$ per group. Red midlines and whiskers indicate medians and interquartile ranges, respectively.

Figure 9. Cytokine expression by decidual B cells. (A \& C) Staggered offset overlay histograms of cytokines expressed by $B$ cells (CD45 ${ }^{+}$CD $3^{-} C D 19^{+} \mathrm{CD} 20^{+}$cells) in the decidua basalis and parietalis. Four representative samples of decidual $B$ cells isolated from women who delivered preterm or term. Control histograms represent signals derived from isotypes or autofluorescence controls. (B \& D) Proportions of B cells expressing IFNY, IL-2, IL-4, IL-6, IL-10, IL-12, IL-35, and TNFa in the decidua basalis and parietalis.

Supplementary Figure 1. B-cell counts in the decidua basalis and decidua parietalis. The number of $\mathrm{CD}_{1} 9^{+} \mathrm{B}$ cells in the decidua basalis (A) and decidua 
parietalis (B) from women who delivered at term with labor (TIL) or without labor (TNL) and women who delivered preterm with labor (PTL) or without labor (PTNL). N = 6-37 per group. Red midlines and whiskers indicate medians and interquartile ranges, respectively.

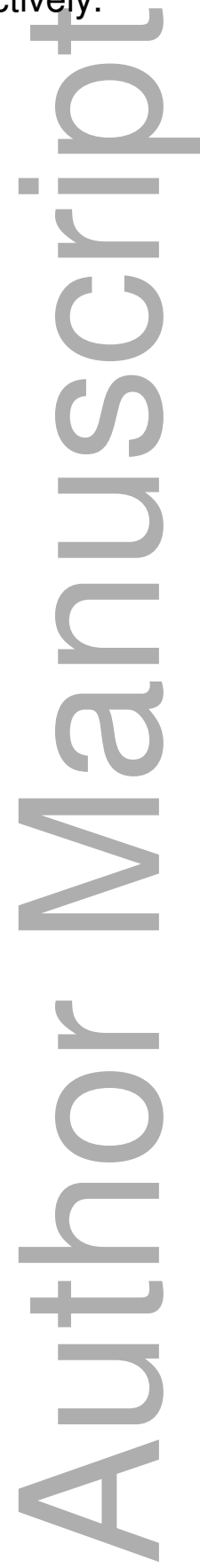

This article is protected by copyright. All rights reserved 
Table 1. Clinical and demographic characteristics of the patient population used to perform immunophenotyping of the decidua basalis

\begin{tabular}{|c|c|c|c|c|c|c|c|c|c|}
\hline , & $\begin{array}{c}\text { Term } \\
\text { without } \\
\text { labor } \\
(n=15)\end{array}$ & $\begin{array}{c}\text { Term labor } \\
(n=14)\end{array}$ & $\begin{array}{c}\text { Term labor } \\
\text { with ACA } \\
(n=10)\end{array}$ & $\begin{array}{c}\text { Term labor } \\
\text { with CCA } \\
(n=13)\end{array}$ & $\begin{array}{c}\text { Preterm } \\
\text { without } \\
\text { labor } \\
(n=4)\end{array}$ & $\begin{array}{l}\text { Preterm } \\
\text { labor } \\
(n=8)\end{array}$ & $\begin{array}{c}\text { Preterm } \\
\text { labor with } \\
\text { ACA } \\
(n=4)\end{array}$ & $\begin{array}{c}\text { Preterm } \\
\text { labor with } \\
\text { CCA } \\
(n=14)\end{array}$ & p-value \\
\hline $\begin{array}{l}\text { Maternal age } \\
(\text { years; median } \\
[\mathrm{QQR}])^{\mathrm{a}}\end{array}$ & $\begin{array}{c}24 \\
(21-29)\end{array}$ & $\begin{array}{c}25 \\
(21.3-30.3)\end{array}$ & $\begin{array}{c}23.5 \\
(22-25.8)\end{array}$ & $\begin{array}{c}24 \\
(22-29)\end{array}$ & $\begin{array}{c}30.5 \\
(28-31)\end{array}$ & $\begin{array}{c}26 \\
(20.5-29)\end{array}$ & $\begin{array}{c}34 \\
(29.5-37)\end{array}$ & $\begin{array}{c}24.5 \\
(21-29.8)\end{array}$ & 0.5 \\
\hline $\begin{array}{l}\text { Body mass index } \\
\left(\mathrm{kg} / \mathrm{m}^{2} ; \text { median }\right. \\
[\mathrm{IQR}])^{\mathrm{a}}\end{array}$ & $\begin{array}{l}31.8 \\
(29.5-34.8)\end{array}$ & $\begin{array}{c}30.2 \\
(25.3-36.8)\end{array}$ & $\begin{array}{c}29 \\
(26.6-33.2)\end{array}$ & $\begin{array}{c}31.3 \\
(26.6-37.3)\end{array}$ & $\begin{array}{c}34.2 \\
(31.8-37.1)\end{array}$ & $\begin{array}{c}30.2 \\
(21.7-41.1)^{\mathrm{c}}\end{array}$ & $\begin{array}{c}28.3 \\
(25.2-34.7)\end{array}$ & $\begin{array}{c}24.3 \\
(21.6-38.2)\end{array}$ & 0.7 \\
\hline Primiparity $^{\mathrm{b}}$ & $\begin{array}{r}13.3 \% \\
(2 / 15)\end{array}$ & $\begin{array}{l}28.6 \% \\
(4 / 14)\end{array}$ & $\begin{array}{c}40 \% \\
(4 / 10)\end{array}$ & $\begin{array}{l}23.1 \% \\
(3 / 13)\end{array}$ & $\begin{array}{l}0 \% \\
(0 / 4)\end{array}$ & $\begin{array}{c}12.5 \% \\
(1 / 8)\end{array}$ & $\begin{array}{l}0 \% \\
(0 / 4)\end{array}$ & $\begin{array}{l}14.3 \% \\
(2 / 14)\end{array}$ & 0.6 \\
\hline Race $^{\text {b }}$ & & & & & & & & & 0.6 \\
\hline $\begin{array}{l}\text { African- } \\
\text { American }\end{array}$ & $\begin{array}{r}73.3 \% \\
(11 / 15)\end{array}$ & $\begin{array}{l}78.6 \% \\
(11 / 14)\end{array}$ & $\begin{array}{c}90 \% \\
(9 / 10)\end{array}$ & $\begin{array}{l}92.3 \% \\
(12 / 13)\end{array}$ & $\begin{array}{l}75 \% \\
(3 / 4)\end{array}$ & $\begin{array}{c}62.5 \% \\
(5 / 8)\end{array}$ & $\begin{array}{l}75 \% \\
(3 / 4)\end{array}$ & $\begin{array}{l}78.6 \% \\
(11 / 14)\end{array}$ & \\
\hline Caucasian & $\begin{array}{c}13.3 \% \\
(2 / 15)\end{array}$ & $\begin{array}{l}21.4 \% \\
(3 / 14)\end{array}$ & $\begin{array}{c}0 \% \\
(0 / 10)\end{array}$ & $\begin{array}{l}7.7 \% \\
(1 / 13)\end{array}$ & $\begin{array}{l}25 \% \\
(1 / 4)\end{array}$ & $\begin{array}{l}25 \% \\
(2 / 8)\end{array}$ & $\begin{array}{l}25 \% \\
(1 / 4)\end{array}$ & $\begin{array}{l}14.3 \% \\
(2 / 14)\end{array}$ & \\
\hline Asian & $\begin{array}{c}0 \% \\
(0 / 15)\end{array}$ & $\begin{array}{c}0 \% \\
(0 / 14)\end{array}$ & $\begin{array}{c}10 \% \\
(1 / 10)\end{array}$ & $\begin{array}{c}0 \% \\
(0 / 13)\end{array}$ & $\begin{array}{l}0 \% \\
(0 / 4)\end{array}$ & $\begin{array}{l}0 \% \\
(0 / 8)\end{array}$ & $\begin{array}{l}0 \% \\
(0 / 4)\end{array}$ & $\begin{array}{c}0 \% \\
(0 / 14)\end{array}$ & \\
\hline Other & $\begin{array}{l}13.3 \% \\
(2 / 15)\end{array}$ & $\begin{array}{c}0 \% \\
(0 / 14)\end{array}$ & $\begin{array}{c}0 \% \\
(0 / 10)\end{array}$ & $\begin{array}{c}0 \% \\
(0 / 13)\end{array}$ & $\begin{array}{l}0 \% \\
(0 / 4)\end{array}$ & $\begin{array}{c}12.5 \% \\
(1 / 8)\end{array}$ & $\begin{array}{l}0 \% \\
(0 / 4)\end{array}$ & $\begin{array}{l}7.1 \% \\
(1 / 14)\end{array}$ & \\
\hline Cesarean section & $\begin{array}{l}100 \% \\
(15 / 15)\end{array}$ & $\begin{array}{l}14.3 \% \\
(2 / 14)\end{array}$ & $\begin{array}{c}20 \% \\
(2 / 10)\end{array}$ & $\begin{array}{l}7.7 \% \\
(1 / 13)\end{array}$ & $\begin{array}{l}100 \% \\
(4 / 4)\end{array}$ & $\begin{array}{c}37.5 \% \\
(3 / 8)\end{array}$ & $\begin{array}{l}25 \% \\
(1 / 4)\end{array}$ & $\begin{array}{l}21.4 \% \\
(3 / 14)\end{array}$ & $<0.001$ \\
\hline $\begin{array}{l}\text { Gestational age at } \\
\text { delivery (weeks; } \\
\text { median }[\mathrm{IQR}])^{\mathrm{a}}\end{array}$ & $\begin{array}{c}39.1 \\
(39-39.4)\end{array}$ & $\begin{array}{c}39 \\
(38.2-40.2)\end{array}$ & $\begin{array}{c}39.4 \\
(38.4-39.8)\end{array}$ & $\begin{array}{c}39.6 \\
(38.9-40.1)\end{array}$ & $\begin{array}{c}34.7 \\
(33.1-36.1)\end{array}$ & $\begin{array}{c}34.4 \\
(31-35.5)\end{array}$ & $\begin{array}{c}34 \\
(32.8-34.7)\end{array}$ & $\begin{array}{c}34.9 \\
(33.3-36.3)\end{array}$ & $<0.001$ \\
\hline
\end{tabular}

This article is protected by copyright. All rights reserved 


\begin{tabular}{|l|c|c|c|c|c|c|c|c|}
\hline Birthweight & 3225 & 3515 & 3392.5 & 3460 & 2025.5 & 1932.5 & 2130 & 2240 \\
(grams) $^{\mathrm{a}}$ & $(2930-$ & $(3121.3-$ & $(3348.8-$ & $(3155-$ & $(1392-$ & $(1401.5-$ & $(1487.5-$ & $(1887.5-$ \\
& $3482.5)$ & $3645)$ & $3628.8)$ & $3665)$ & $2798.8)$ & $3233.8)$ & $2776.3)$ & $2322.5)$ \\
\hline
\end{tabular}

Data are given as median (interquartile range, IQR) and percentage $(\mathrm{n} / \mathrm{N}) . \mathrm{ACA}=$ acute chorioamnionitis; $\mathrm{CCA}=$ chronic chorioamnionitis $($ please see Methods for definitions).

${ }^{a}$ Kruskal-Wallis test.

${ }^{\text {b}}$ Fisher's exact test.

${ }^{\circ}$ One missing data.

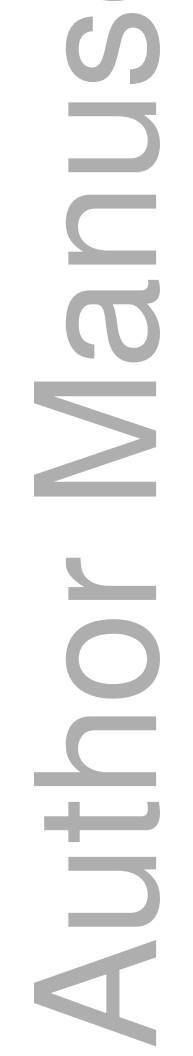

This article is protected by copyright. All rights reserved 
Table 2. Clinical and demographic characteristics of the patient population used to perform immunophenotyping of the decidua parietalis

\begin{tabular}{|c|c|c|c|c|c|c|c|c|c|}
\hline 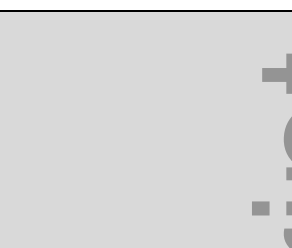 & $\begin{array}{c}\text { Term } \\
\text { without } \\
\text { labor } \\
(n=16)\end{array}$ & $\begin{array}{l}\text { Term labor } \\
\qquad(n=14)\end{array}$ & $\begin{array}{l}\text { Term labor } \\
\text { with ACA } \\
(n=10)\end{array}$ & $\begin{array}{c}\text { Term labor } \\
\text { with CCA } \\
(n=14)\end{array}$ & $\begin{array}{l}\text { Preterm } \\
\text { without } \\
\text { labor } \\
(n=4)\end{array}$ & $\begin{array}{l}\text { Preterm } \\
\text { labor } \\
(n=9)\end{array}$ & $\begin{array}{c}\text { Preterm } \\
\text { labor with } \\
\text { ACA } \\
(n=4)\end{array}$ & $\begin{array}{c}\text { Preterm } \\
\text { labor with } \\
\text { CCA } \\
(n=14)\end{array}$ & $p$-value \\
\hline $\begin{array}{l}\text { Maternal age } \\
(\text { years; median } \\
\left.\left[{ }^{[Q R}\right]\right)^{a}\end{array}$ & $\begin{array}{c}24 \\
(21-28.8)\end{array}$ & $\begin{array}{c}25 \\
(21.3-30.3)\end{array}$ & $\begin{array}{c}23.5 \\
(22-25.8)\end{array}$ & $\begin{array}{c}24 \\
(22-29)\end{array}$ & $\begin{array}{c}30.5 \\
(28-31)\end{array}$ & $\begin{array}{c}28 \\
(21-32)\end{array}$ & $\begin{array}{c}34 \\
(29.5-37)\end{array}$ & $\begin{array}{c}24.5 \\
(21-29.8)\end{array}$ & 0.5 \\
\hline $\begin{array}{l}\text { Body mass index } \\
\left(\mathrm{kg} / \mathrm{m}^{2} ; \text { median }\right. \\
[\mathrm{IQR}])^{\mathrm{a}}\end{array}$ & $\begin{array}{c}31.5 \\
(29.5-34.4)^{c}\end{array}$ & $\begin{array}{c}30.2 \\
(25.3-36.8)\end{array}$ & $\begin{array}{c}29 \\
(26.6-33.2)\end{array}$ & $\begin{array}{c}32.8 \\
(26.7-37.1)\end{array}$ & $\begin{array}{c}34.2 \\
(31.8-37.1)\end{array}$ & $\begin{array}{c}32.9 \\
(21.9-40)^{c}\end{array}$ & $\begin{array}{c}28.3 \\
(25.2-34.7)\end{array}$ & $\begin{array}{c}24.3 \\
(21.6-38.2)\end{array}$ & 0.7 \\
\hline Primiparity ${ }^{b}$ & $\begin{array}{l}12.5 \% \\
(2 / 16)\end{array}$ & $\begin{array}{l}28.6 \% \\
(4 / 14)\end{array}$ & $\begin{array}{l}40 \% \\
(4 / 10)\end{array}$ & $\begin{array}{l}21.4 \% \\
(3 / 14)\end{array}$ & $\begin{array}{l}0 \% \\
(0 / 4)\end{array}$ & $\begin{array}{c}11.1 \% \\
(1 / 9)\end{array}$ & $\begin{array}{l}0 \% \\
(0 / 4)\end{array}$ & $\begin{array}{l}14.3 \% \\
(2 / 14)\end{array}$ & 0.6 \\
\hline Race $^{b}$ & & & & & & & & & 0.5 \\
\hline $\begin{array}{l}\text { African- } \\
\text { American }\end{array}$ & $\begin{array}{c}75 \% \\
-(12 / 16) \\
\end{array}$ & $\begin{array}{l}78.6 \% \\
(11 / 14)\end{array}$ & $\begin{array}{c}90 \% \\
(9 / 10)\end{array}$ & $\begin{array}{l}92.9 \% \\
(13 / 14)\end{array}$ & $\begin{array}{l}75 \% \\
(3 / 4)\end{array}$ & $\begin{array}{c}55.6 \% \\
(5 / 9)\end{array}$ & $\begin{array}{l}75 \% \\
(3 / 4)\end{array}$ & $\begin{array}{l}78.6 \% \\
(11 / 14)\end{array}$ & \\
\hline Caucasian & $\begin{array}{l}18.8 \% \\
(3 / 16)\end{array}$ & $\begin{array}{l}21.4 \% \\
(3 / 14)\end{array}$ & $\begin{array}{c}0 \% \\
(0 / 10)\end{array}$ & $\begin{array}{l}7.1 \% \\
(1 / 14)\end{array}$ & $\begin{array}{l}25 \% \\
(1 / 4)\end{array}$ & $\begin{array}{c}33.3 \% \\
(3 / 9)\end{array}$ & $\begin{array}{l}25 \% \\
(1 / 4)\end{array}$ & $\begin{array}{l}14.3 \% \\
(2 / 14)\end{array}$ & \\
\hline Asian & $\begin{array}{c}0 \% \\
(0 / 16)\end{array}$ & $\begin{array}{c}0 \% \\
(0 / 14)\end{array}$ & $\begin{array}{c}10 \% \\
(1 / 10)\end{array}$ & $\begin{array}{c}0 \% \\
(0 / 14)\end{array}$ & $\begin{array}{l}0 \% \\
(0 / 4)\end{array}$ & $\begin{array}{l}0 \% \\
(0 / 9)\end{array}$ & $\begin{array}{l}0 \% \\
(0 / 4)\end{array}$ & $\begin{array}{c}0 \% \\
(0 / 14)\end{array}$ & \\
\hline Other & $\begin{array}{l}6.2 \% \\
(1 / 16)\end{array}$ & $\begin{array}{c}0 \% \\
(0 / 14)\end{array}$ & $\begin{array}{c}0 \% \\
(0 / 10)\end{array}$ & $\begin{array}{c}0 \% \\
(0 / 14)\end{array}$ & $\begin{array}{l}0 \% \\
(0 / 4)\end{array}$ & $\begin{array}{l}11.1 \% \\
(1 / 9)\end{array}$ & $\begin{array}{l}0 \% \\
(0 / 4)\end{array}$ & $\begin{array}{l}7.1 \% \\
(1 / 14)\end{array}$ & \\
\hline Cesarean section & $\begin{array}{r}100 \% \\
(16 / 16)\end{array}$ & $\begin{array}{l}14.3 \% \\
(2 / 14)\end{array}$ & $\begin{array}{l}20 \% \\
(2 / 10)\end{array}$ & $\begin{array}{l}7.1 \% \\
(1 / 14)\end{array}$ & $\begin{array}{l}100 \% \\
(4 / 4)\end{array}$ & $\begin{array}{c}33.3 \% \\
(3 / 9)\end{array}$ & $\begin{array}{l}25 \% \\
(1 / 4)\end{array}$ & $\begin{array}{l}21.4 \% \\
(3 / 14)\end{array}$ & $<0.001$ \\
\hline
\end{tabular}

This article is protected by copyright. All rights reserved 


\begin{tabular}{|c|c|c|c|c|c|c|c|c|c|}
\hline $\begin{array}{l}\text { Gestational age at } \\
\text { delivery (weeks; } \\
\text { median }[\mathrm{IQR}])^{\mathrm{a}}\end{array}$ & $\begin{array}{c}39.1 \\
(39-39.2)\end{array}$ & $\begin{array}{c}39 \\
(38.2-40.2)\end{array}$ & $\begin{array}{c}39.4 \\
(38.4-39.8)\end{array}$ & $\begin{array}{c}39.7 \\
(38.9-40.1)\end{array}$ & $\begin{array}{c}34.7 \\
(33.1-36.1)\end{array}$ & $\begin{array}{c}34.7 \\
(31.3-35.9)\end{array}$ & $\begin{array}{c}34 \\
(32.8-34.7)\end{array}$ & $\begin{array}{c}34.9 \\
(33.3-36.3)\end{array}$ & $<0.001$ \\
\hline $\begin{array}{l}\text { Birthweight } \\
\text { (grams) }^{\text {a }}\end{array}$ & $\begin{array}{l}3222.5 \\
(2940- \\
3456.3)\end{array}$ & $\begin{array}{c}3515 \\
(3121.3- \\
3645)\end{array}$ & $\begin{array}{r}3392.5 \\
(3348.8- \\
3628.8)\end{array}$ & $\begin{array}{c}3510 \\
(3206.3- \\
3706.3)\end{array}$ & $\begin{array}{l}2025.5 \\
(1392- \\
2798.8)\end{array}$ & $\begin{array}{l}2160 \\
(1435- \\
3155)\end{array}$ & $\begin{array}{c}2130 \\
(1487.5- \\
2776.3)\end{array}$ & $\begin{array}{c}2240 \\
(1887.5- \\
2322.5)\end{array}$ & $<0.001$ \\
\hline
\end{tabular}

Data are given as median (interquartile range, IQR) and percentage $(n / N)$. ACA = acute chorioamnionitis; CCA = chronic chorioamnionitis $($ please see Methods for definitions).

${ }^{a}$ Kruskal-Wallis test.

${ }^{b}$ Fisher's exact test

${ }^{\circ}$ One missing data.

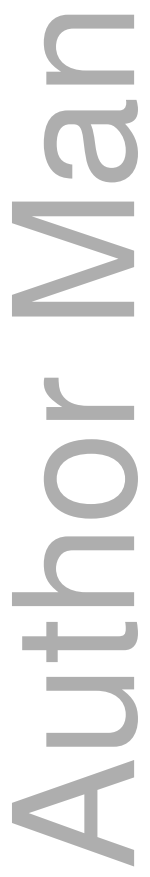

This article is protected by copyright. All rights reserved 
Table 3. Markers to identify $B$ cells subsets

\begin{tabular}{|c|c|c|}
\hline B cell subsets & Immunophenotype & References \\
\hline B1 B cells & $\mathrm{CD}_{19}{ }^{+} \mathrm{CD} 27^{+} \mathrm{CD} 43^{+}$ & Griffin DO et.al[1, 2], Torring C et.al[3], Inui M et.al[4] \\
\hline B2 B cells & $\mathrm{CD}_{19}{ }^{+} \mathrm{CD} 23^{+}$ & Griffin DO et.al[1], Deng C et.al[5] \\
\hline $\begin{array}{l}\text { Transitional B } \\
\text { cells }\end{array}$ & CD19+CD38 ${ }^{\mathrm{hi}} \mathrm{CD} 24^{\mathrm{hi}}$ & $\begin{array}{l}\text { Marie-Cardine A et.al[6], Ha Y et.al[7], Seifert M et.al[8], } \\
\text { de Masson A et.al[9], Cherukuri A et.al[10], Heidt S } \\
\text { et.al[11], Latorre I et.al[12], Tebbe B et.al[13], Luk F } \\
\text { et.al[14], Demoersman J et.al[15], Li S et.al[16] }\end{array}$ \\
\hline Naïve B cells & $D 19^{+} \mathrm{CD} 27^{-} \lg \mathrm{D}^{+}$ & $\begin{array}{l}\text { Guerreiro-Cacais A et.al[17], So N et.al[18], Heath E } \\
\text { et.al[19], Cantaert T et.al[20], Toapanta F et.al[21], } \\
\text { Jansen M et.al[22], Castaneda D et.al[23], Wu X et.al[24], } \\
\text { Nakayama Y et.al[25] }\end{array}$ \\
\hline $\begin{array}{l}\text { Class-switche } \\
\text { memory B cel }\end{array}$ & & $\begin{array}{l}\text { Anolik J et.al[26], Tian C et.al[27], Ghannam A et.al[28], } \\
\text { Palanichamy A et.al[29], Berkowska M et.al[30], Morbach } \\
\text { H et.al[31], Wu Y et.al[32], So N et.al[18], Heath E } \\
\text { et.al[19], Topanta F et.al[21], Labuda L et.al[33], } \\
\text { Degauque N et.al[34], Zhang L et.al[35], Bagnara D } \\
\text { et.al[36], Czarnowicki T et.al[37], Hayashi M et.al[38], } \\
\text { Mensah F et.al[39], Woda M et.al[40], Castaneda D } \\
\text { et.al[23], Martins C et.al[41] }\end{array}$ \\
\hline $\begin{array}{l}\text { Non class- } \\
\text { switched } \\
\text { memory B cells }\end{array}$ & $\mathrm{CD} 19^{+} \mathrm{CD} 27^{+} \lg \mathrm{D}^{+}$ & $\begin{array}{l}\text { Anolik J et.al[26], Tian C et.al[27], Palanichamy A } \\
\text { et.al[29], Colonna-Romano G et.al[42], Jacobi A et.al[43], } \\
\text { Wu Y et.al[32], So N et.al[18], Heath E et.al[19], Topanta } \\
\text { F et.al[21], Weller S et.al[44], Labuda LA et.al[33], } \\
\text { Clemente A et.al[45], Czarnowicki T et.al[37], Mensah F } \\
\text { et.al[39], Castaneda D et.al[23], Martins C et.al[41], } \\
\text { Corneth O et.al[46], Torigoe M et.al[47], Hu F, et.al[48] }\end{array}$ \\
\hline Plasmablasts & $\begin{array}{l}\mathrm{CD} 19^{+} \mathrm{CD} 20^{-} \\
\mathrm{CD}^{-} 8^{+} \mathrm{CD} 24^{-}\end{array}$ & Morbach H et.al[49], Lin W et.al[50], Benett M et.al[51] \\
\hline
\end{tabular}

This article is protected by copyright. All rights reserved 


\section{References}

1. Griffin, D.O., N.E. Holodick, and T.L. Rothstein, Human B1 cells in umbilical cord and adult peripheral blood express the novel phenotype CD20+CD27+CD43+CD70. J Exp Med, 2011. 208(1): p. 67-80.

2. Griffin, D.O. and T.L. Rothstein, $A$ small CD11b(+) human B1 cell subpopulation stimulates $T$ cells and is expanded in lupus. J Exp Med, 2011. 208(13): p. 2591-8.

3. Torring, C., et al., The B1-cell subpopulation is diminished in patients with relapsing-remitting multiple sclerosis. J Neuroimmunol, 2013. 262(1-2): p. 92-9.

4. Inui, M., et al., Human CD43+ B cells are closely related not only to memory B cells phenotypically but also to plasmablasts developmentally in healthy individuals. Int Immunol, 2015. 27(7): p. 345-55.

5. Deng, C., et al., The Imbalance of B-Lymphocyte Subsets in Subjects with Different Glucose Tolerance: Relationship with Metabolic Parameter and Disease Status. J Diabetes Res, 2017. 2017: p. 5052812.

6. Marie-Cardine, A., et al., Transitional B cells in humans: characterization and insight from B lymphocyte reconstitution after hematopoietic stem cell transplantation. Clin Immunol, 2008. 127(1): p. 14-25.

7. Ha, Y.J., et al., Characterization of phenotypically distinct B-cell subsets and receptor-stimulated mitogenactivated protein kinase activation in human cord blood B cells. J Leukoc Biol, 2008. 84(6): p. 1557-64.

8. Seifert, M., et al., Cellular origin and pathophysiology of chronic lymphocytic leukemia. J Exp Med, 2012. 209(12): p. 2183-98.

9. de Masson, A., H. Le Buanec, and J.D. Bouaziz, Purification and immunophenotypic characterization of human $B$ cells with regulatory functions. Methods Mol Biol, 2014. 1190: p. 45-52.

10. Cherukuri, A., et al., Immunologic human renal allograft injury associates with an altered IL-10/TNF-alpha expression ratio in regulatory B cells. J Am Soc Nephrol, 2014. 25(7): p. 1575-85.

11. Heidt, S., et al., B Cell Markers of Operational Tolerance Can Discriminate Acute Kidney Allograft Rejection From Stable Graft Function. Transplantation, 2015. 99(5): p. 1058-1064.

12. Latorre, I., et al., Calcineurin and mTOR inhibitors have opposing effects on regulatory T cells while reducing regulatory B cell populations in kidney transplant recipients. Transpl Immunol, 2016. 35: p. 1-6.

13. Tebbe, B., et al., Renal Transplant Recipients Treated with Calcineurin-Inhibitors Lack Circulating Immature Transitional CD19+CD24hiCD38hi Regulatory B-Lymphocytes. PLoS One, 2016. 11(4): p. e0153170.

14. Luk, F., et al., Inflammatory Conditions Dictate the Effect of Mesenchymal Stem or Stromal Cells on B Cell Function. Front Immunol, 2017. 8: p. 1042.

15. Demoersman, J., et al., B cell subset distribution is altered in patients with severe periodontitis. PLoS One, 2018. 13(2): p. e0192986.

This article is protected by copyright. All rights reserved 
16. Li, S., et al., Marked elevation of circulating CD19(+)CD38(hi)CD24(hi) transitional B cells give protection against neonatal sepsis. Pediatr Neonatol, 2018. 59(3): p. 296-304.

17. Guerreiro-Cacais, A.O., J. Levitskaya, and V. Levitsky, B cell receptor triggering sensitizes human B cells to TRAILinduced apoptosis. J Leukoc Biol, 2010. 88(5): p. 937-45.

18. So, N.S., M.A. Ostrowski, and S.D. Gray-Owen, Vigorous response of human innate functioning IgM memory $B$ cells upon infection by Neisseria gonorrhoeae. J Immunol, 2012. 188(8): p. 4008-22.

19. Heath, E., et al., Epstein-Barr virus infection of naive B cells in vitro frequently selects clones with mutated immunoglobulin genotypes: implications for virus biology. PLoS Pathog, 2012. 8(5): p. e1002697.

20. Cantaert, T., et al., Increased numbers of CD5+ B lymphocytes with a regulatory phenotype in spondylarthritis. Arthritis Rheum, 2012. 64(6): p. 1859-68.

21. Toapanta, F.R., P.J. Bernal, and M.B. Sztein, Diverse phosphorylation patterns of B cell receptor-associated signaling in naive and memory human $B$ cells revealed by phosphoflow, a powerful technique to study signaling at the single cell level. Front Cell Infect Microbiol, 2012. 2: p. 128.

22. Jansen, M.A., et al., Decreased memory B cells and increased CD8 memory $T$ cells in blood of breastfed children: the generation R study. PLoS One, 2015. 10(5): p. e0126019.

23. Castaneda, D.M., D.M. Salgado, and C.F. Narvaez, B cells naturally induced during dengue virus infection release soluble CD27, the plasma level of which is associated with severe forms of pediatric dengue. Virology, 2016. 497: p. $136-145$.

24. Wu, X., et al., Impaired T Cell-dependent Humoral Immune Response Associated with Juvenile-onset Recurrent Respiratory Papillomatosis Progression. Sci Rep, 2016. 6: p. 36378.

25. Nakayama, Y., et al., Aiolos Overexpression in Systemic Lupus Erythematosus B Cell Subtypes and BAFF-Induced Memory B Cell Differentiation Are Reduced by CC-220 Modulation of Cereblon Activity. J Immunol, 2017. 199(7): p. $2388-2407$.

26. Anolik, J.H., et al., Cutting edge: anti-tumor necrosis factor therapy in rheumatoid arthritis inhibits memory $B$ lymphocytes via effects on lymphoid germinal centers and follicular dendritic cell networks. J Immunol, 2008. 180(2): p. 688-92.

27. Tian, C., et al., Immunodominance of the VH1-46 antibody gene segment in the primary repertoire of human rotavirus-specific $B$ cells is reduced in the memory compartment through somatic mutation of nondominant clones. J Immunol, 2008. 180(5): p. 3279-88.

28. Ghannam, A., et al., Human C3 deficiency associated with impairments in dendritic cell differentiation, memory $B$ cells, and regulatory T cells. J Immunol, 2008. 181(7): p. 5158-66.

29. Palanichamy, A., et al., Novel human transitional B cell populations revealed by B cell depletion therapy. J Immunol, 2009. 182(10): p. 5982-93.

This article is protected by copyright. All rights reserved 
30. Berkowska, M.A., et al., Human memory B cells originate from three distinct germinal center-dependent andindependent maturation pathways. Blood, 2011. 118(8): p. 2150-8.

31. Morbach, H., et al., Activated memory B cells may function as antigen-presenting cells in the joints of children with juvenile idiopathic arthritis. Arthritis Rheum, 2011. 63(11): p. 3458-66.

32. Wu, Y.C., D. Kipling, and D.K. Dunn-Walters, The relationship between CD27 negative and positive B cell populations in human peripheral blood. Front Immunol, 2011. 2: p. 81.

33. Labuda, L.A., et al., Alterations in peripheral blood B cell subsets and dynamics of $B$ cell responses during human schistosomiasis. PLoS Negl Trop Dis, 2013. 7(3): p. e2094.

34. Degauque, N., et al., Characterization of antigen-specific B cells using nominal antigen-coated flow-beads. PLoS One, 2013. 8(12): p. e84273.

35. Zhang, L., et al., Plasmacytoid dendritic cells mediate synergistic effects of HIV and lipopolysaccharide on CD27+ IgD- memory B cell apoptosis. J Virol, 2014. 88(19): p. 11430-41.

36. Bagnara, D., et al., A Reassessment of IgM Memory Subsets in Humans. J Immunol, 2015. 195(8): p. $3716-24$.

37. Czarnowicki, T., et al., Diverse activation and differentiation of multiple B-cell subsets in patients with atopic dermatitis but not in patients with psoriasis. J Allergy Clin Immunol, 2016. 137(1): p. 118-129 e5.

38. Hayashi, M., et al., IL-10-producing regulatory B cells are decreased in patients with psoriasis. J Dermatol Sci, 2016. 81(2): p. 93-100.

39. Mensah, F., et al., Extended B cell phenotype in patients with myalgic encephalomyelitis/chronic fatigue syndrome: a cross-sectional study. Clin Exp Immunol, 2016. 184(2): p. 237-47.

40. Woda, M., et al., Dynamics of Dengue Virus (DENV)-Specific B Cells in the Response to DENV Serotype 1 Infections, Using Flow Cytometry With Labeled Virions. J Infect Dis, 2016. 214(7): p. 1001-9.

41. Martins, C., et al., Pregnancy alters the circulating B cell compartment in atopic asthmatic women, and transitional B cells are positively associated with the development of allergy manifestations in their progeny. Am J Reprod Immunol, 2016. 76(6): p. 465-474.

42. Colonna-Romano, G., et al., A double-negative (IgD-CD27-) B cell population is increased in the peripheral blood of elderly people. Mech Ageing Dev, 2009. 130(10): p. 681-90.

43. Jacobi, A.M., et al., Effect of long-term belimumab treatment on B cells in systemic lupus erythematosus: extension of a phase II, double-blind, placebo-controlled, dose-ranging study. Arthritis Rheum, 2010. 62(1): p. 201-10.

44. Weller, S., et al., IgM+IgD+CD27+ B cells are markedly reduced in IRAK-4-, MyD88-, and TIRAP- but not UNC-93Bdeficient patients. Blood, 2012. 120(25): p. 4992-5001.

45. Clemente, A., et al., Increased STAT3 phosphorylation on CD27(+) B-cells from common variable immunodeficiency disease patients. Clin Immunol, 2015. 161(2): p. 77-88.

This article is protected by copyright. All rights reserved 
46. Corneth, O.B.J., et al., Enhanced Bruton's Tyrosine Kinase Activity in Peripheral Blood B Lymphocytes From Patients With Autoimmune Disease. Arthritis Rheumatol, 2017. 69(6): p. 1313-1324.

47. Torigoe, M., et al., Metabolic Reprogramming Commits Differentiation of Human CD27(+)IgD(+) B Cells to Plasmablasts or CD27(-)IgD(-) Cells. J Immunol, 2017. 199(2): p. 425-434.

48. Hu, F., et al., Impaired $C D 27(+) \lg D(+)$ B Cells With Altered Gene Signature in Rheumatoid Arthritis. Front Immunol, 2018. 9: p. 626.

49. Morbach, $\mathrm{H}_{\text {., }}$ et al., Reference values for B cell subpopulations from infancy to adulthood. Clin Exp Immunol, 2010. 162(2): p. 271-9.

50. Lin, W., et al., Circulating plasmablasts/plasma cells: a potential biomarker for IgG4-related disease. Arthritis Res Ther, 2017. 19(1): p. 25.

51. Bennett, M.S., et al., Human mucosal-associated invariant T (MAIT) cells possess capacity for B cell help. J Leukoc Biol, 2017. 102(5): p. 1261-1269.

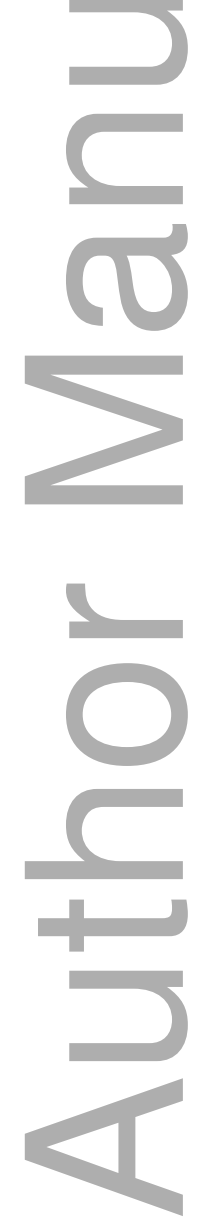

This article is protected by copyright. All rights reserved 
A

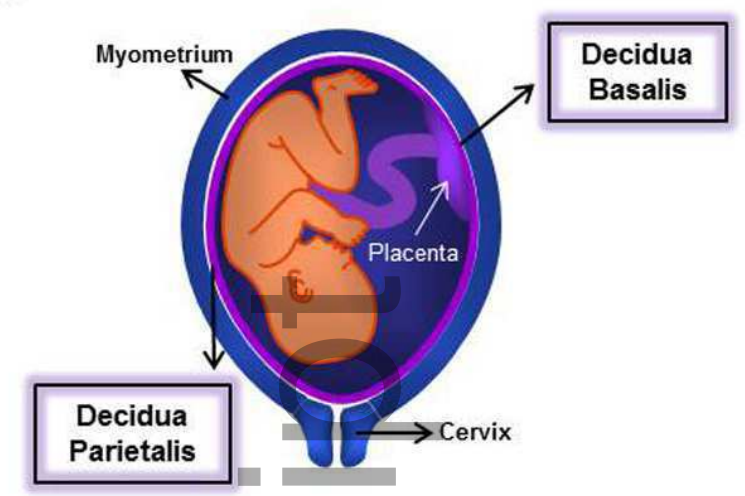

C

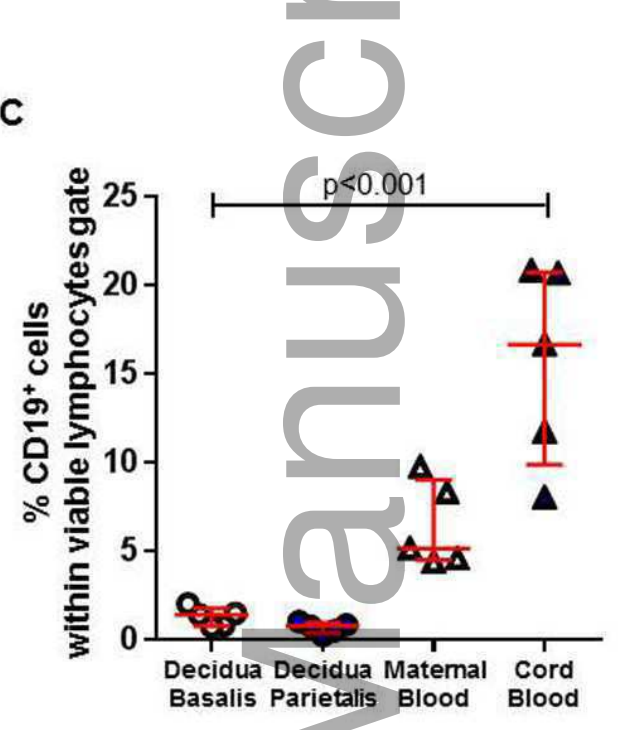

E

Decidua Basalis

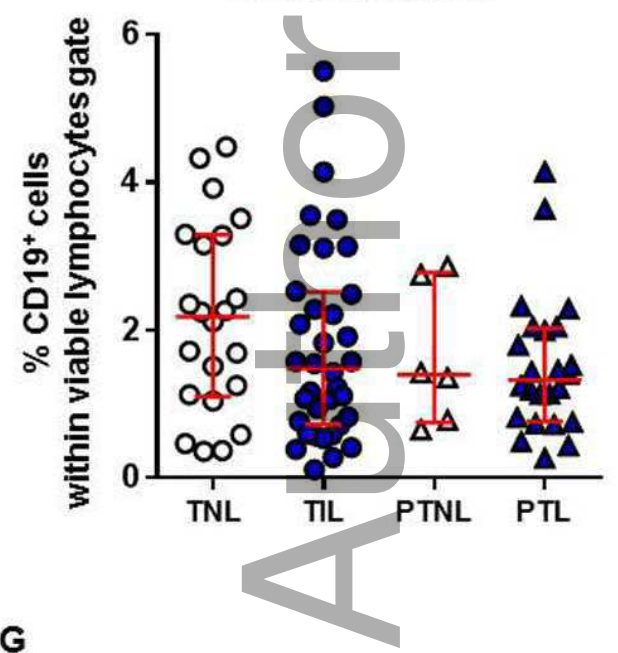

G

$$
\text { Decidua Parietalis }
$$

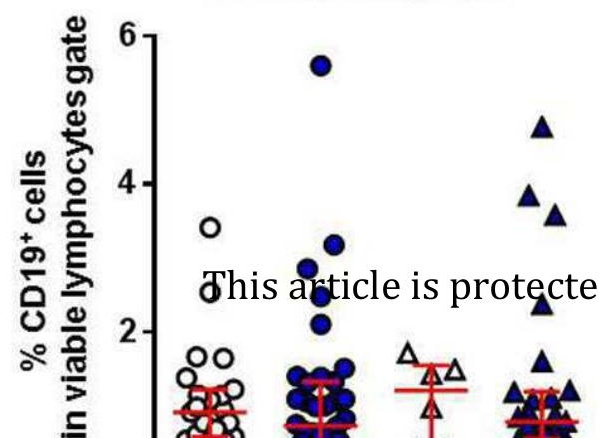

B

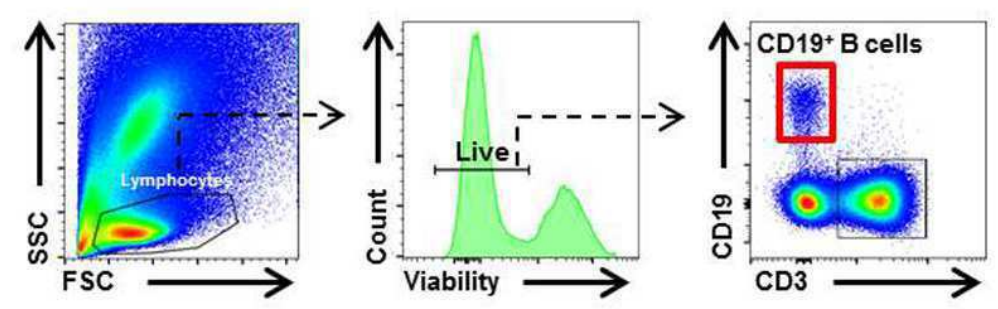

D

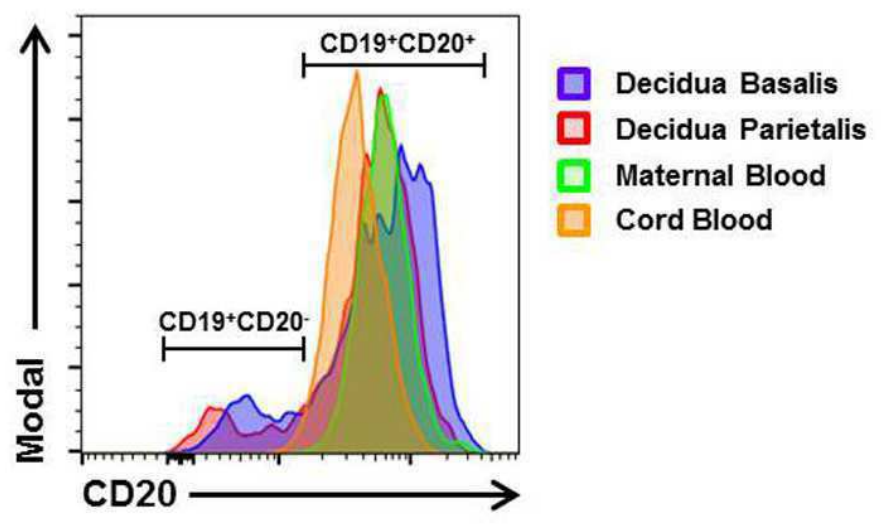

F

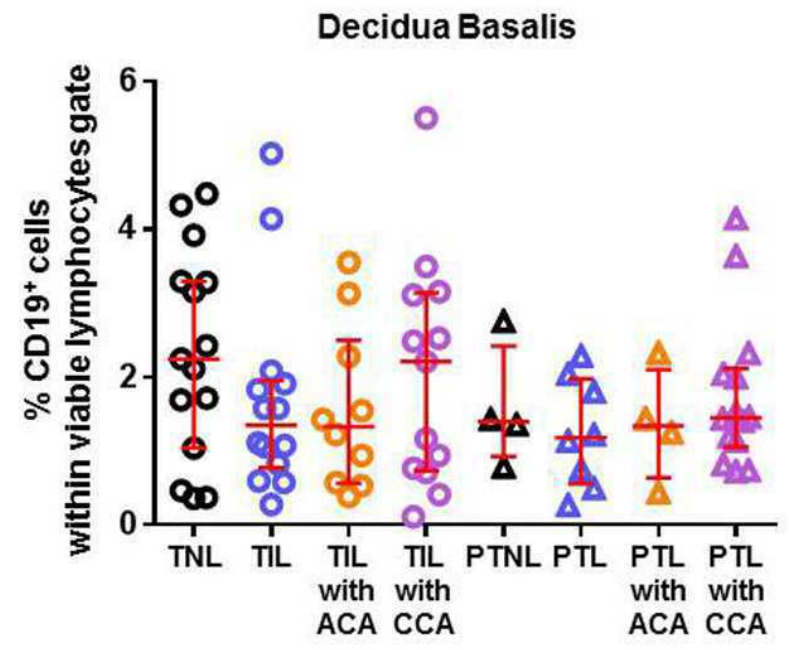

H

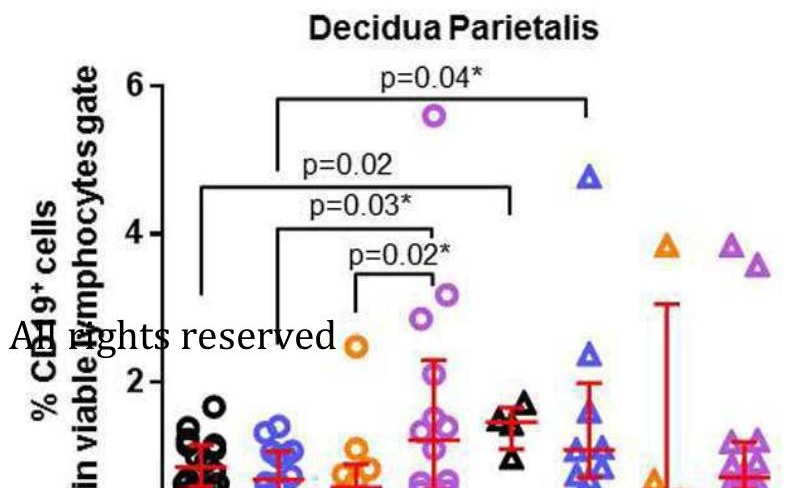


A

B2 B cells

B cells

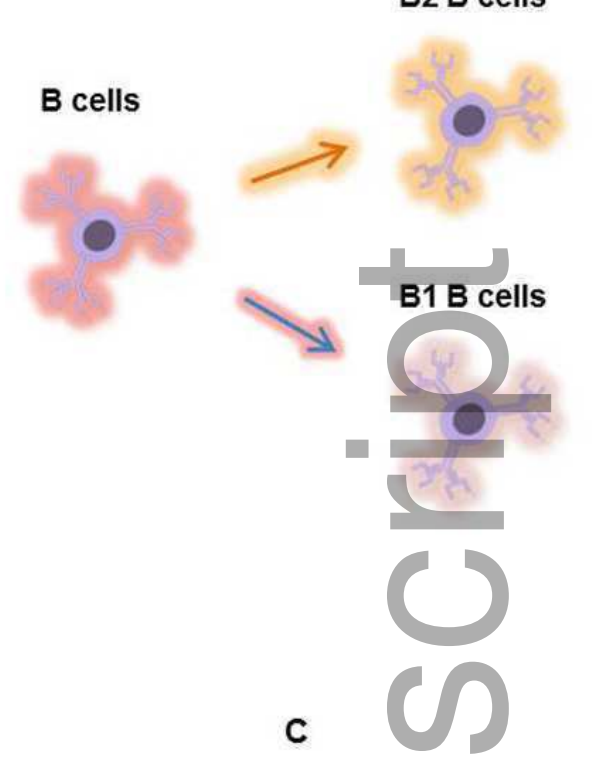

B

Class-switched memory $B$ cells

B1 or B2
transitional B Naïve B cells
cells
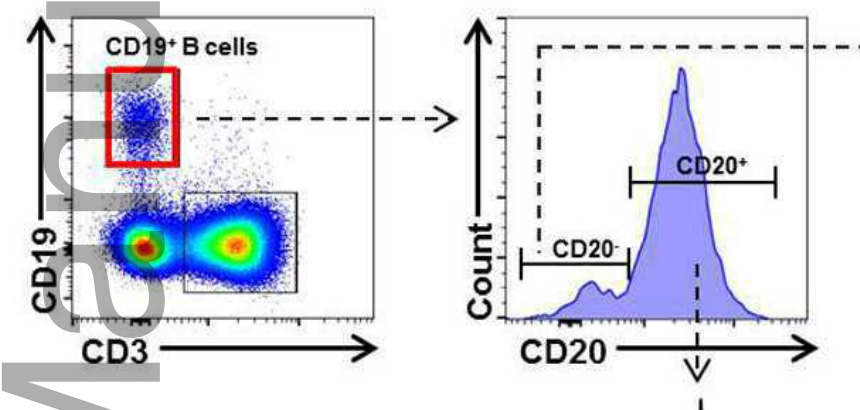

Plasmablasts

Non-class-switched memory B cells

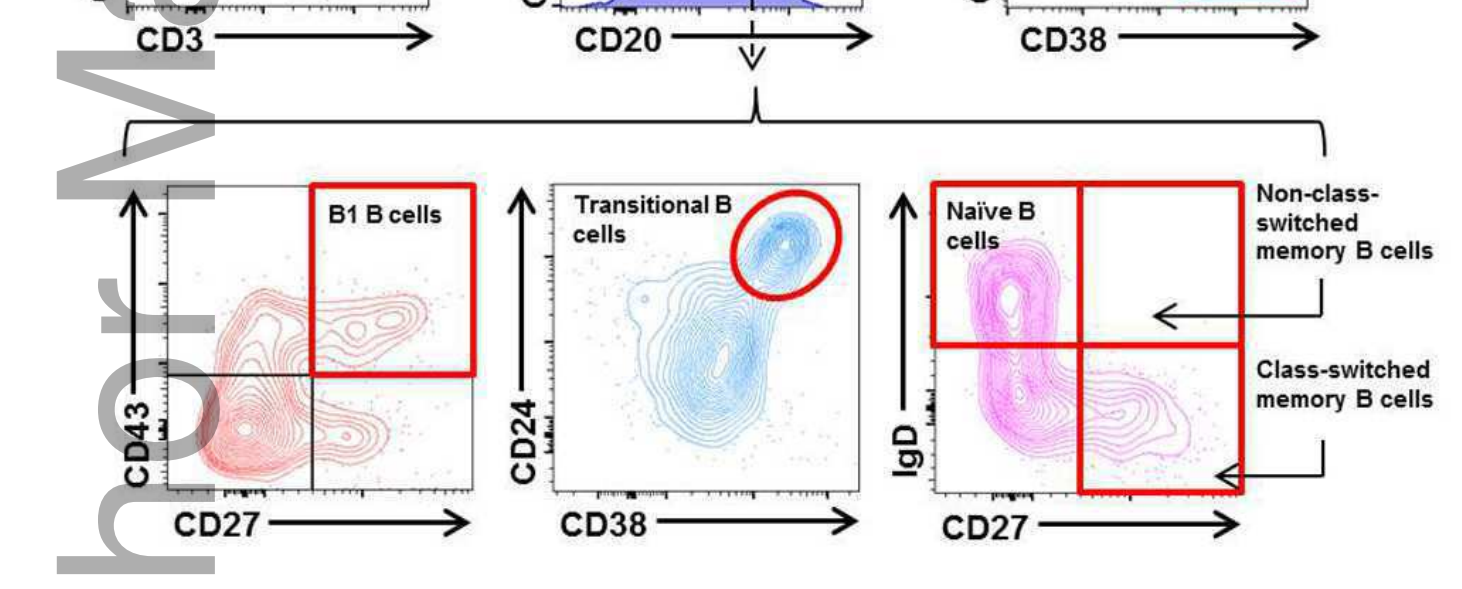

D
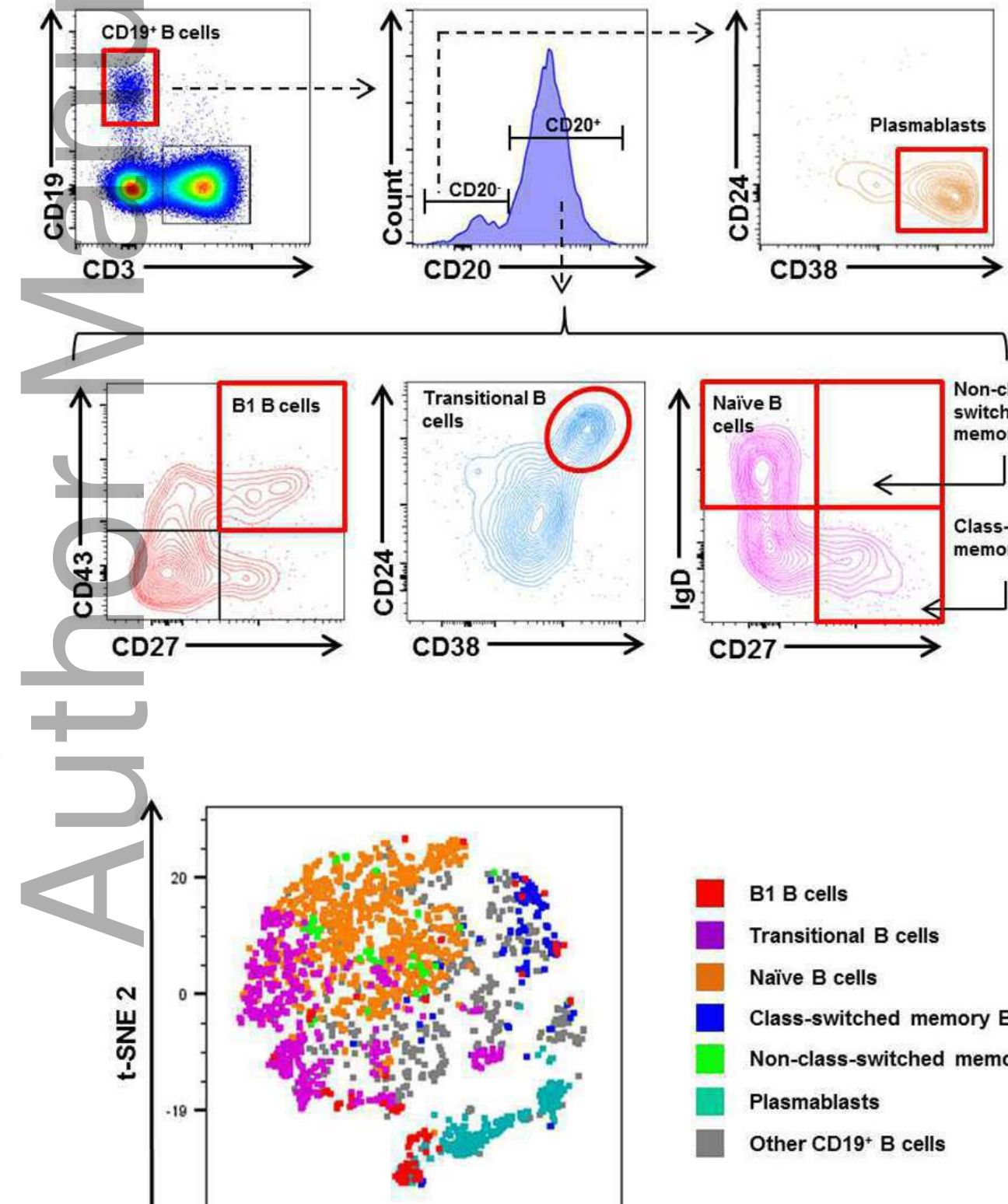

This article is protected by copyright. All rights reserved

B1 B cells

Transitional B cells

Naïve $B$ cells

Class-switched memory B cells

Non-class-switched memory B cells

Plasmablasts

Other CD19+ B cells 
A

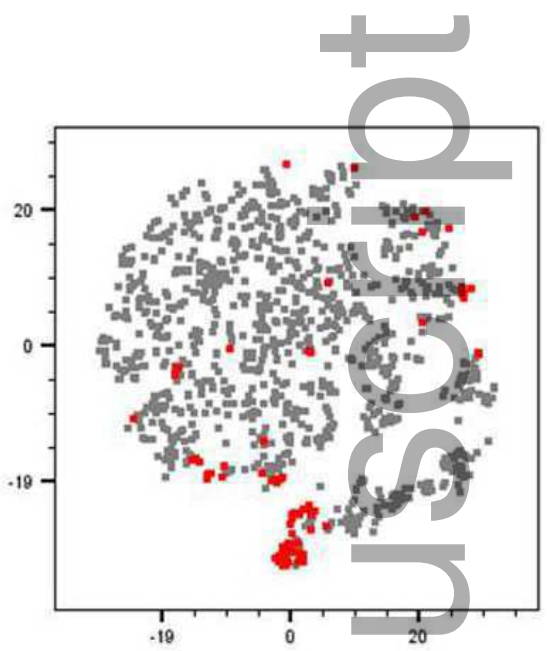

B1 B cells

Other $\mathrm{CD} 19^{+} \mathrm{B}$ cells
B

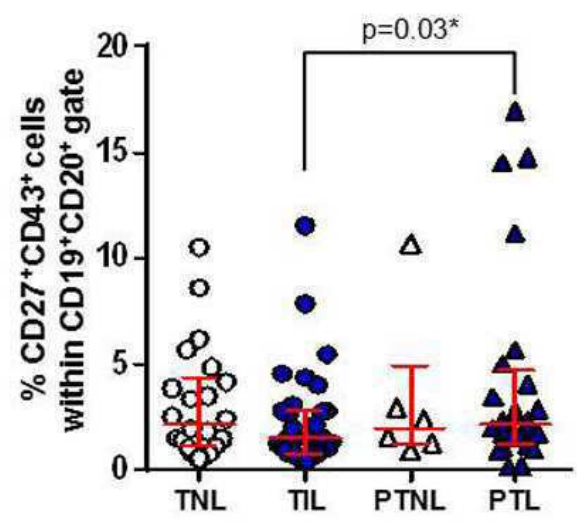

D

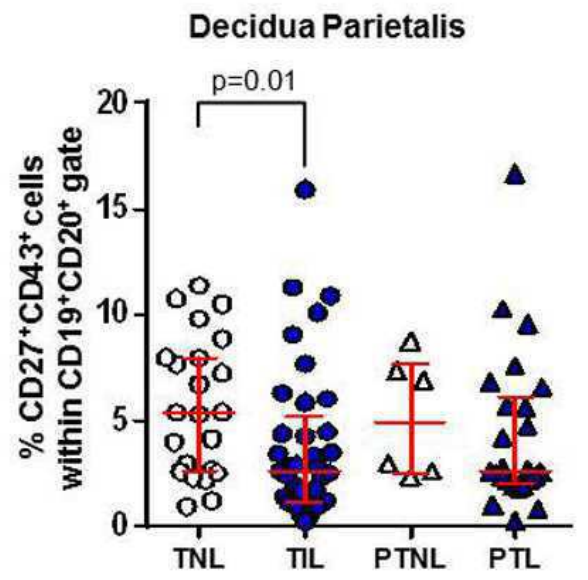

C

Decidua Basalis

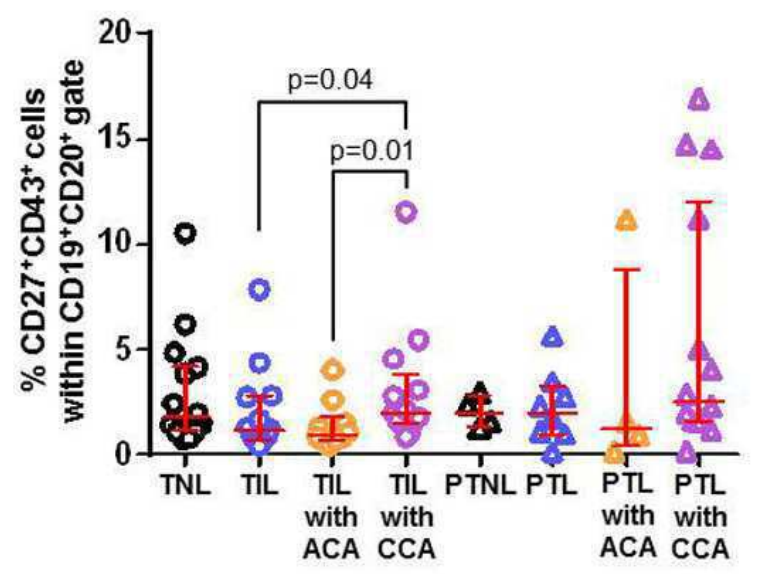

E

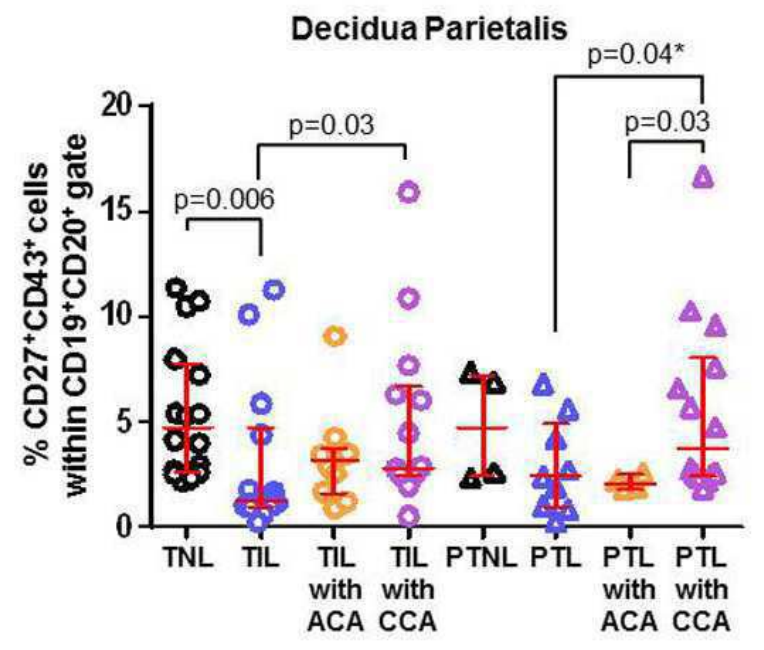




\section{A}

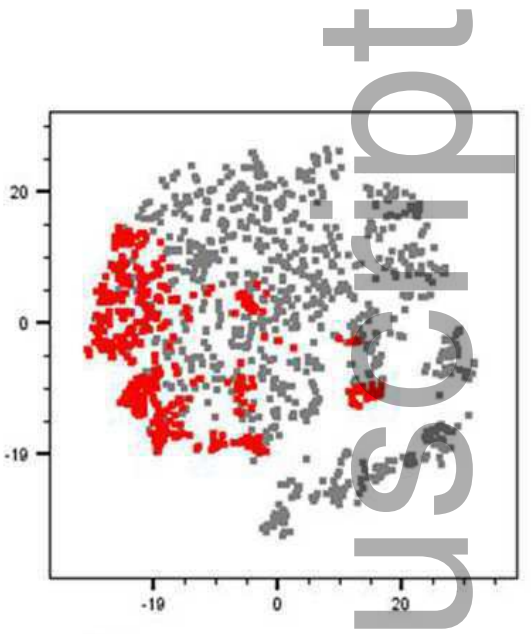

Transitional B cells Other CD19+ B cells
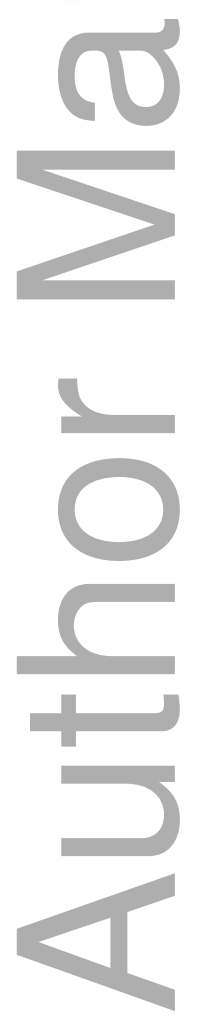

B

Decidua Basalis

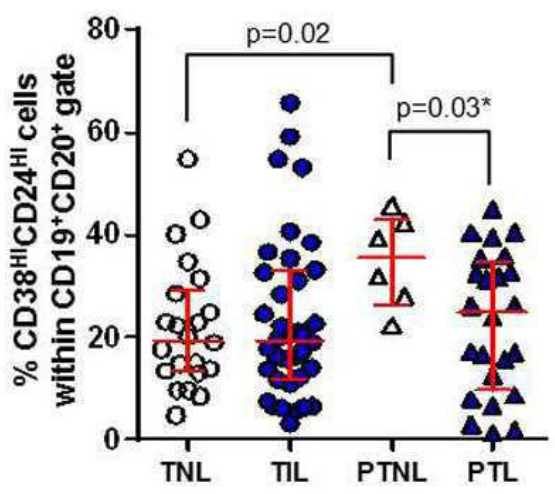

D

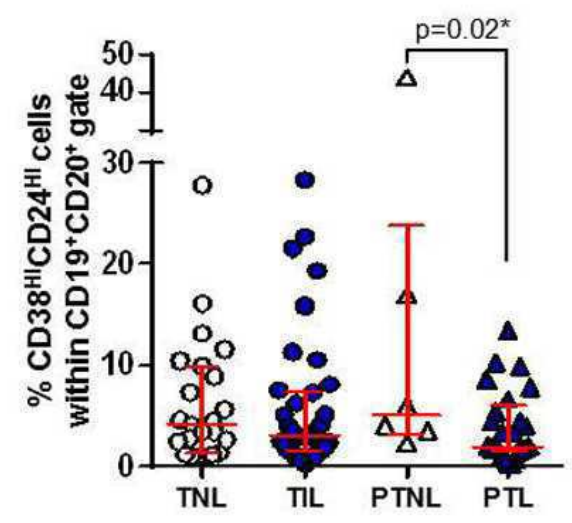

E
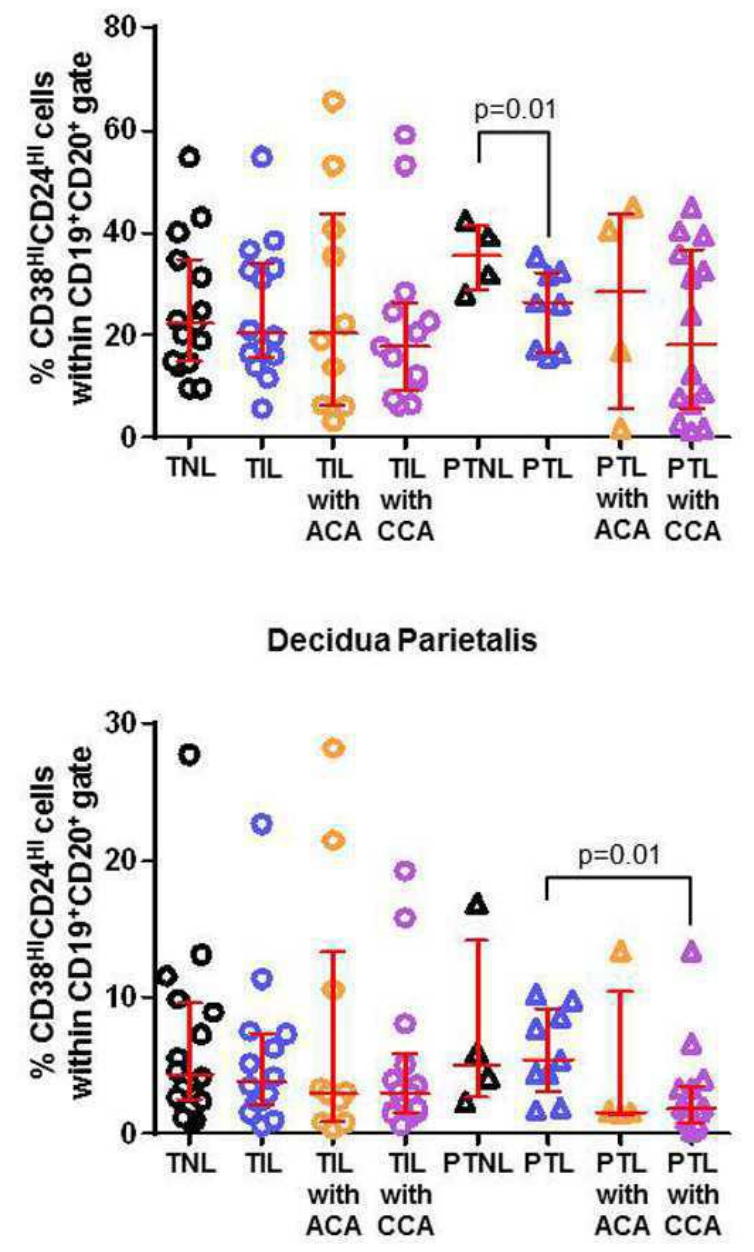

Decidua Parietalis

aji_13102_f4.eps 
B

A

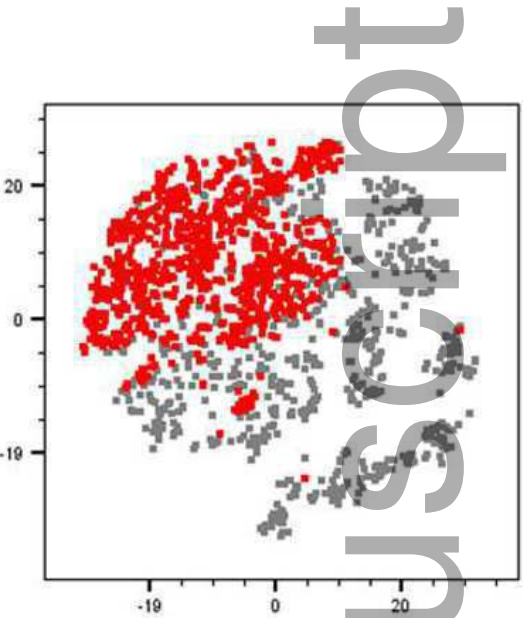

Naîve B cells

Other $\mathrm{CD} 19^{+} \mathrm{B}$ cells
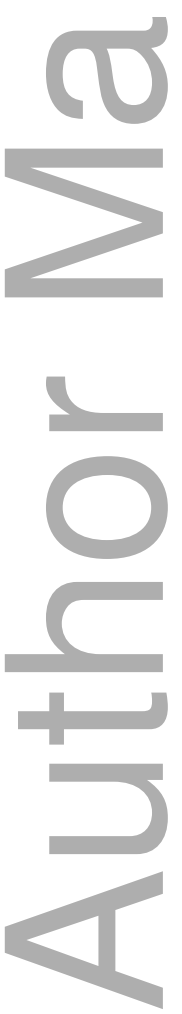

Decidua Basalis

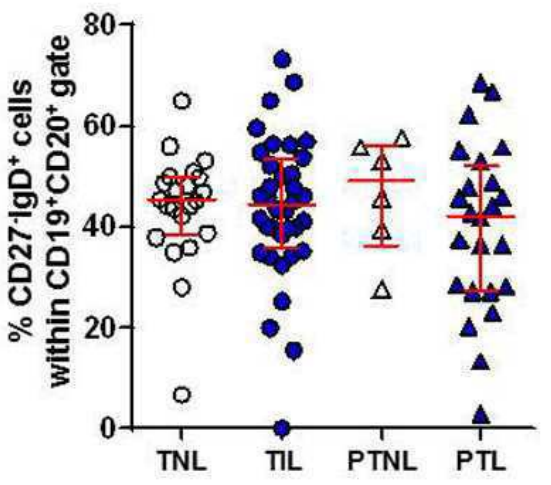

D

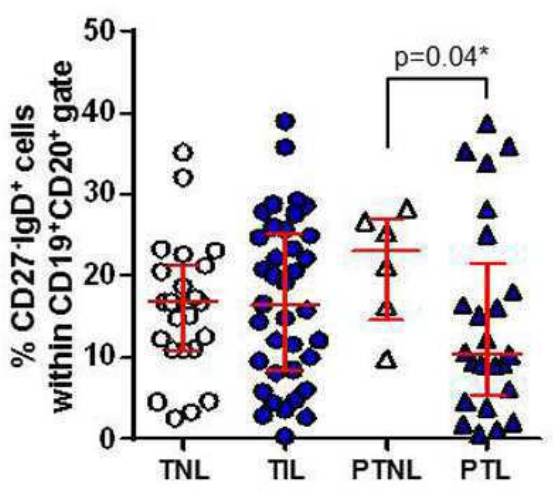

C

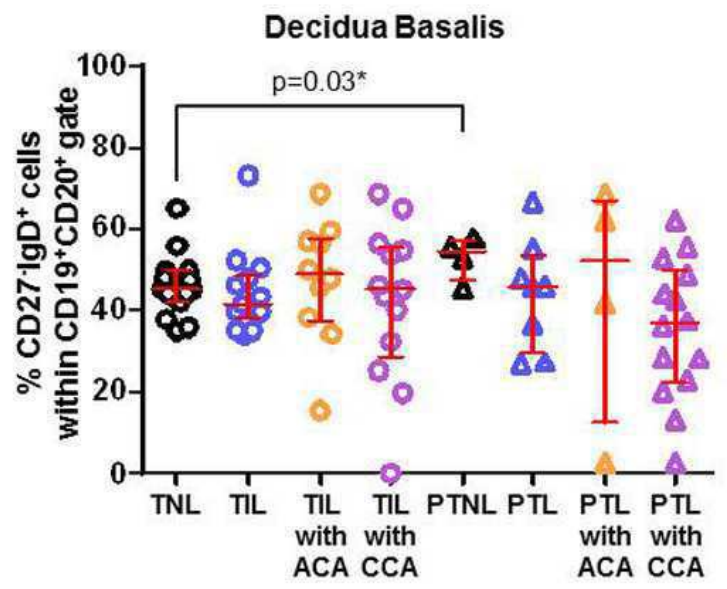

E

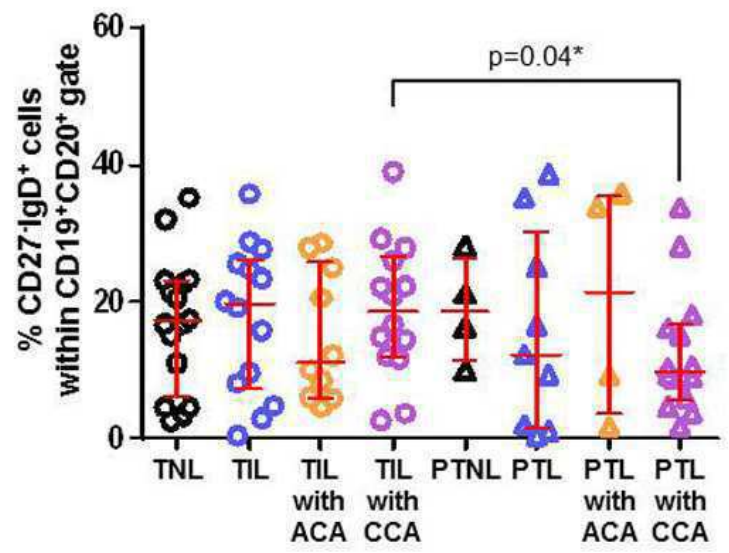

aji_13102_f5.eps 


\section{A}

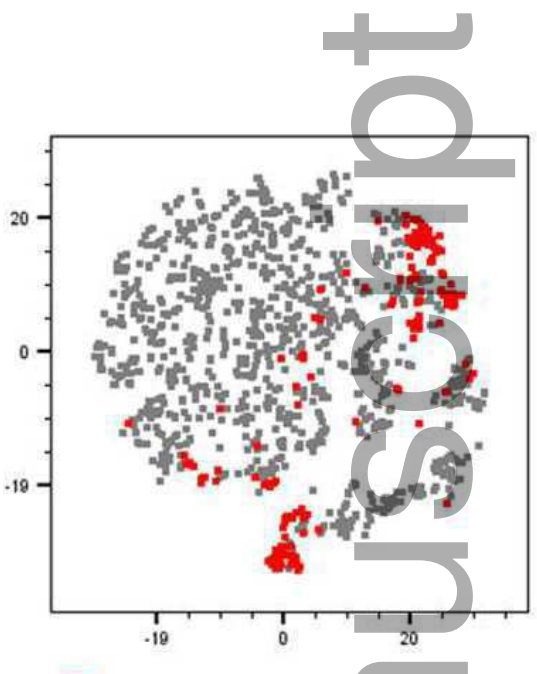

Class-switched memory B cells Other $\mathrm{CD} 19^{+} \mathrm{B}$ cells
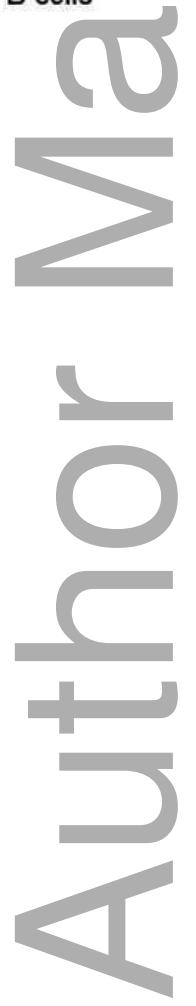

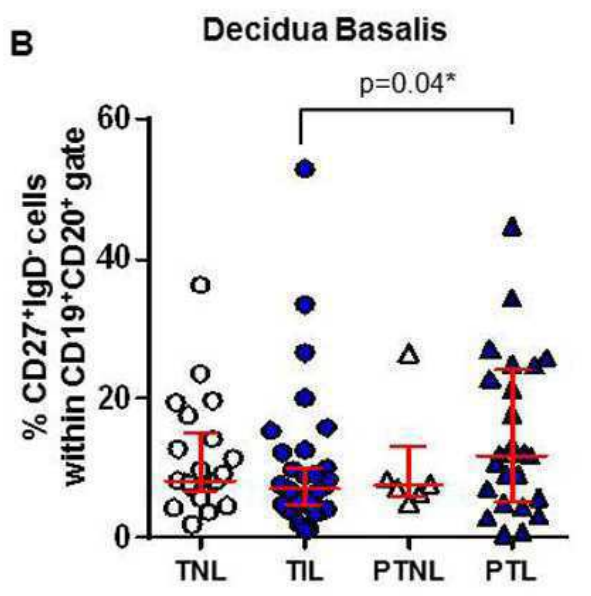

D

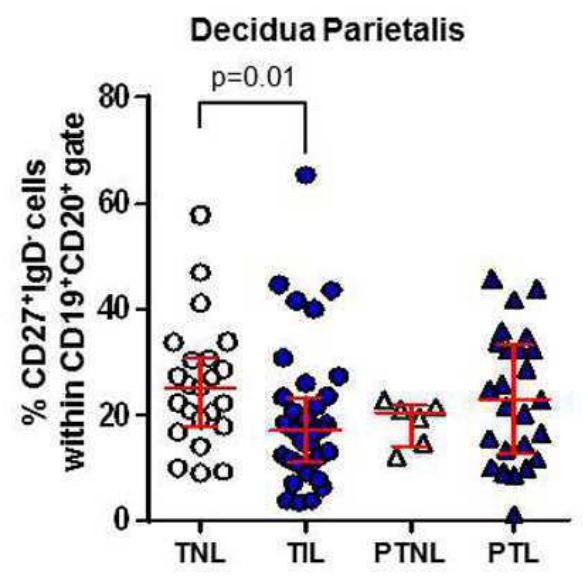

aji_13102_f6.eps
C

\section{Decidua Basalis}

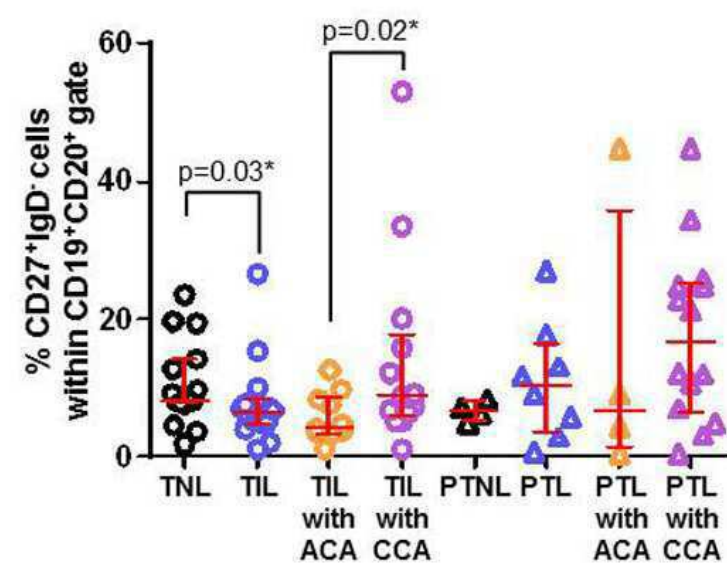

E

\section{Decidua Parietalis}

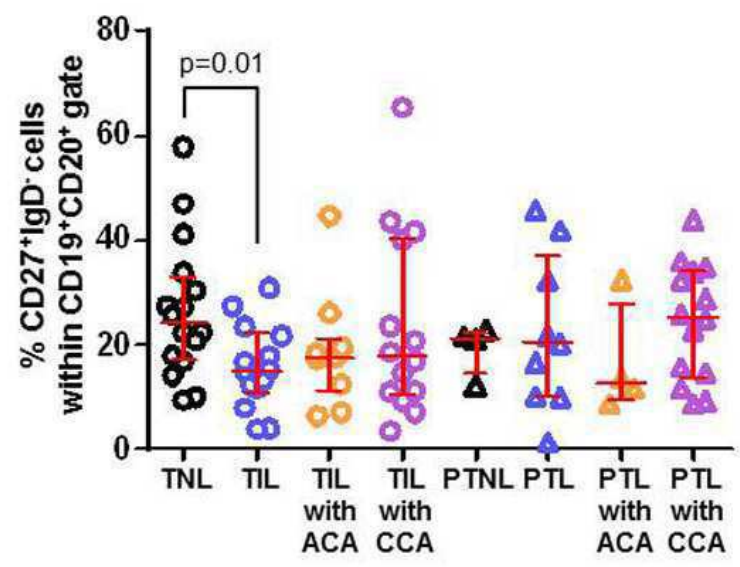




\section{A}

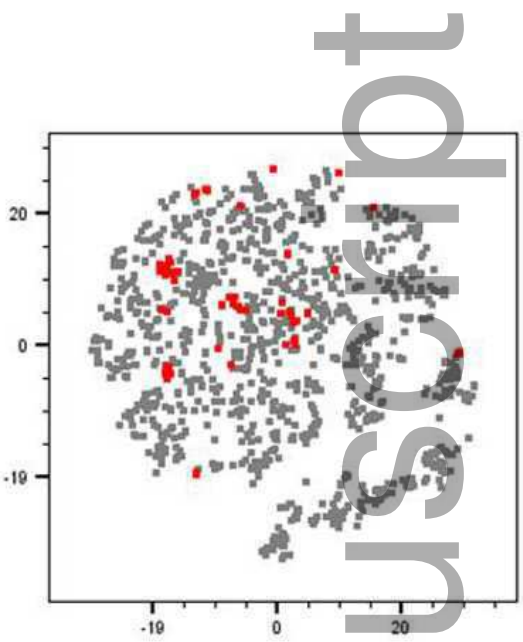

Non-class-switched memory B cells Other CD19+ $B$ cells
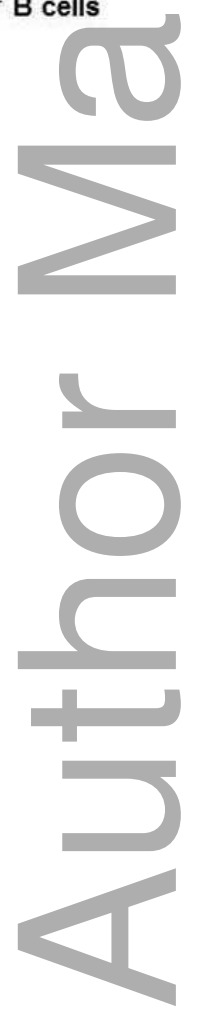

B

Decidua Basalis

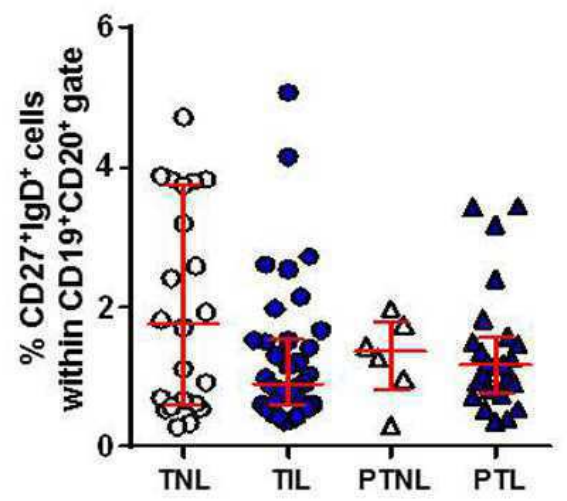

D

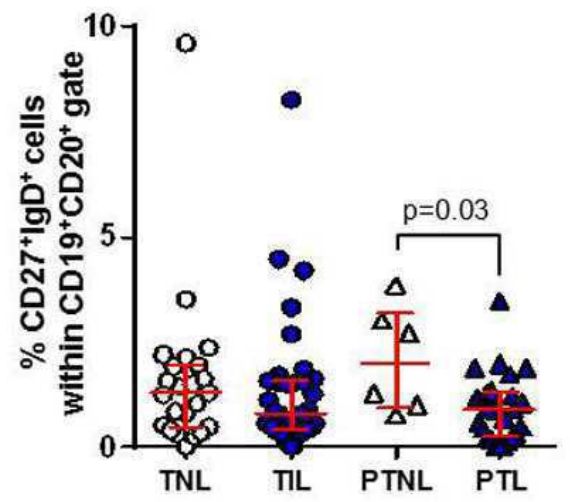

aji_13102_f7.eps
C

Decidua Basalis
$\mathbf{E}$

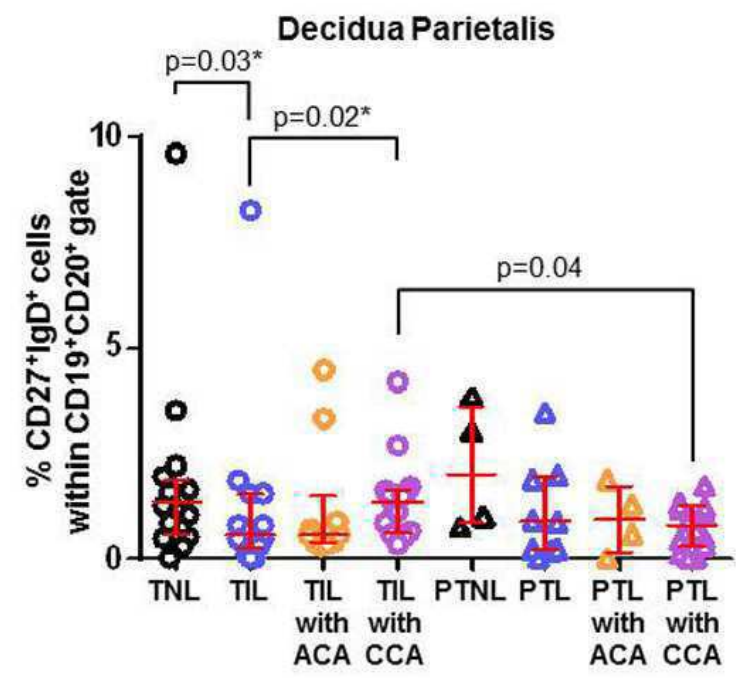




\begin{abstract}
A
\end{abstract}

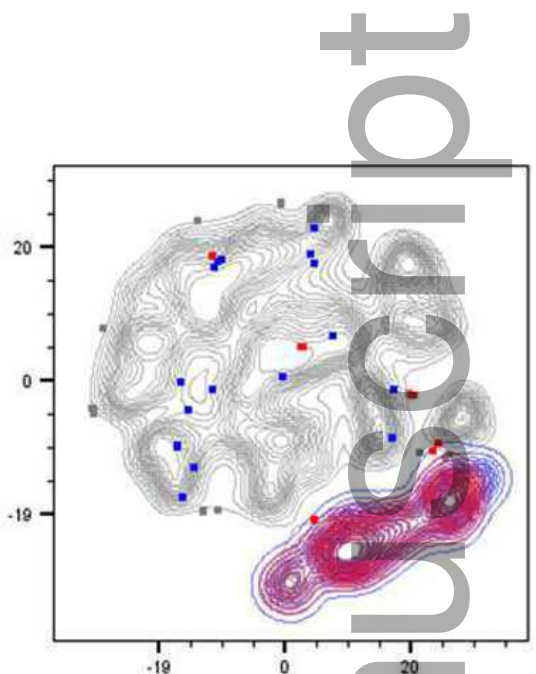

Plasmablasts

CD19+CD20- B cells

Other CD19+ B cells
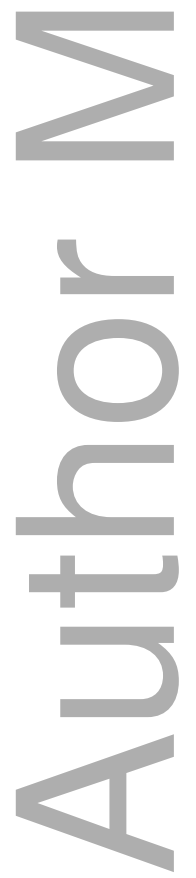

Decidua Basalis

B

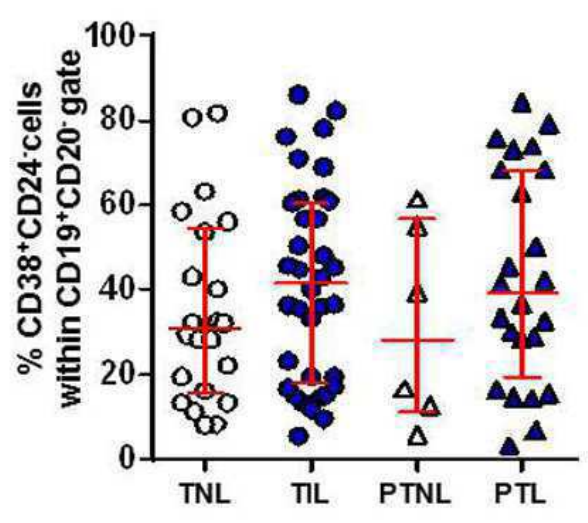

D

Decidua Parietalis

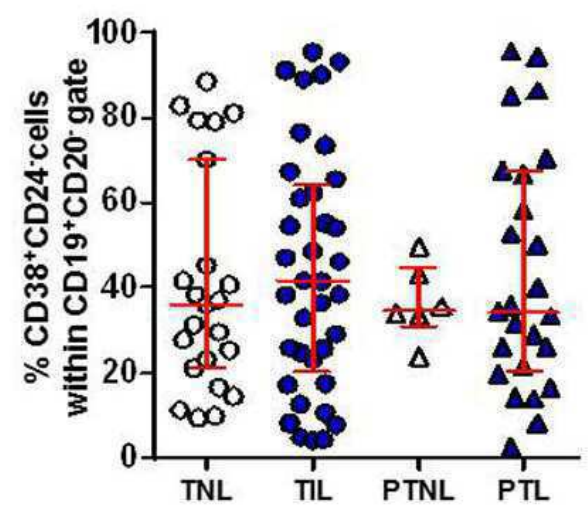

aji_13102_f8.eps

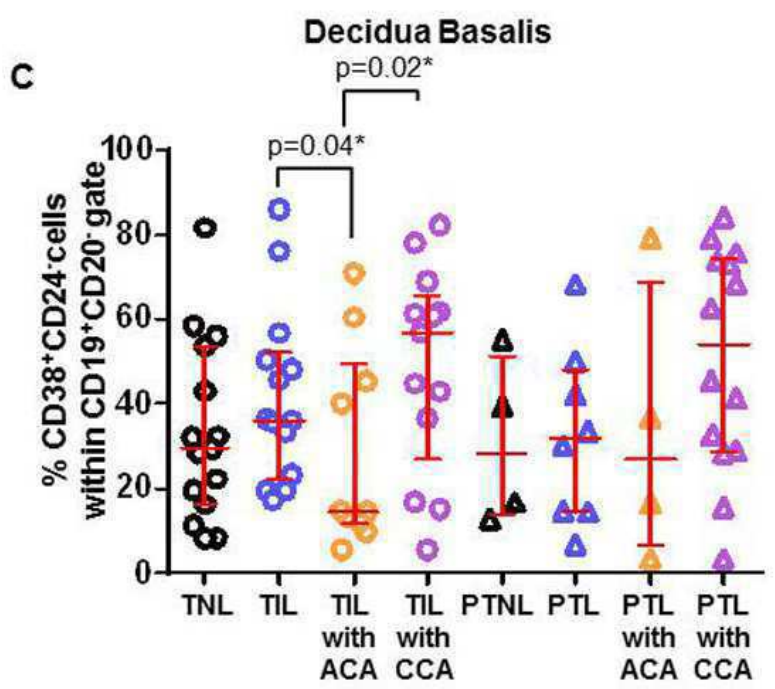

E

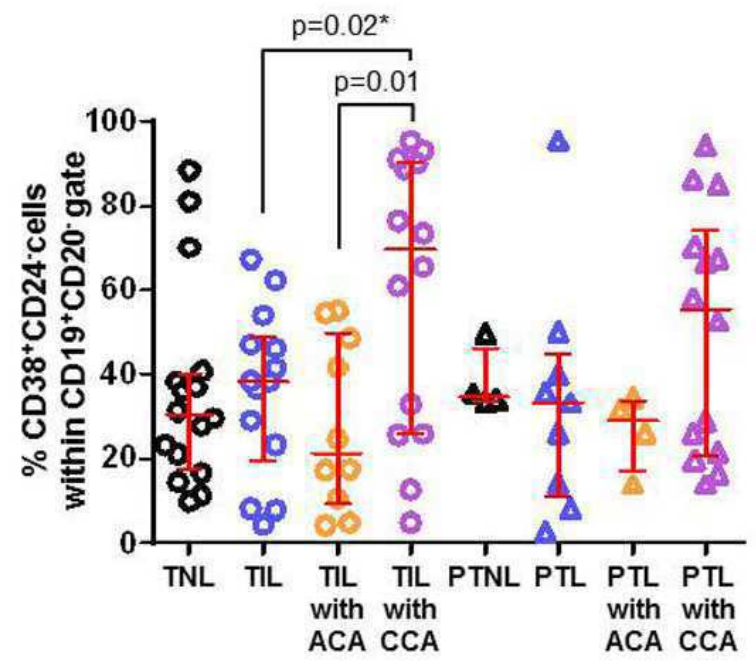


A

Decidua Basalis

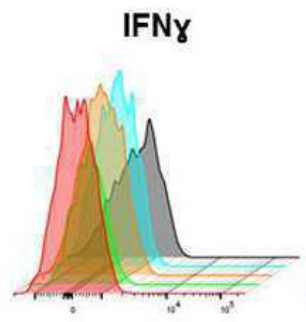

IL-2

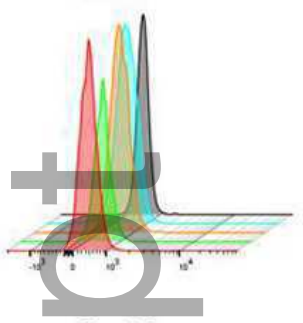

IL-10

IL-12

IL-35
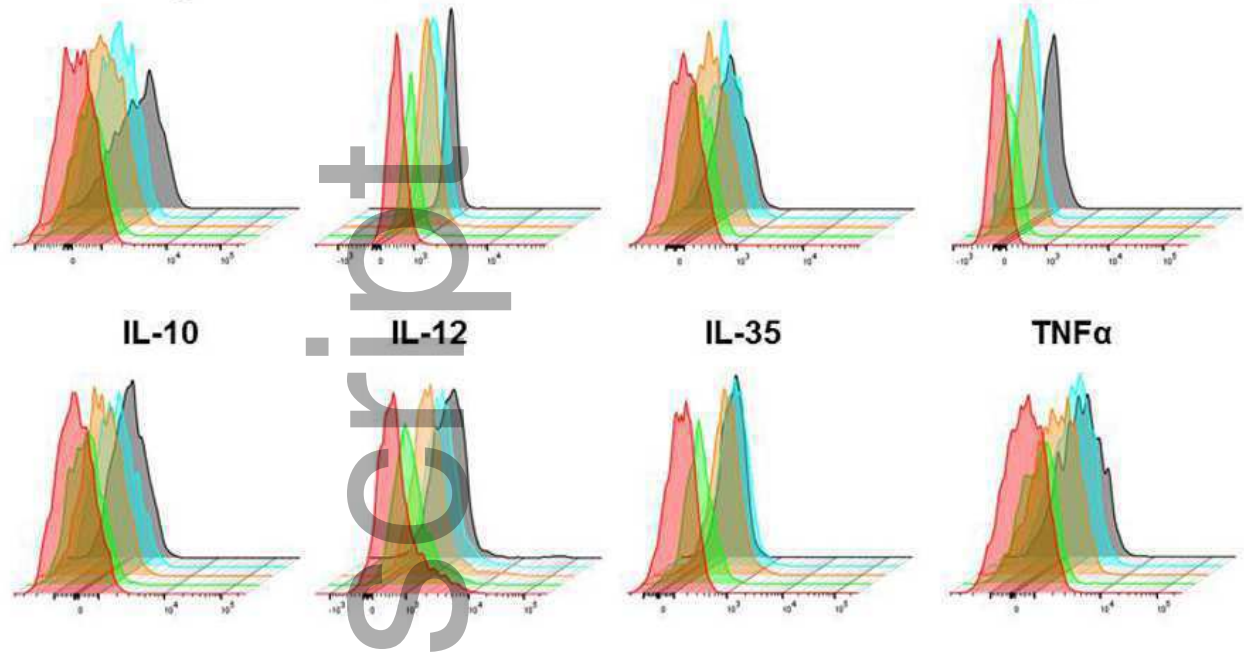

C

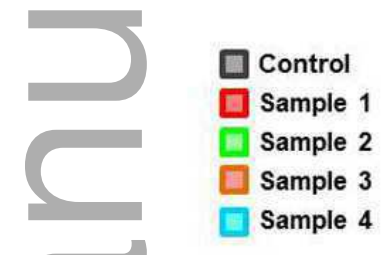

Decidua Parietalis
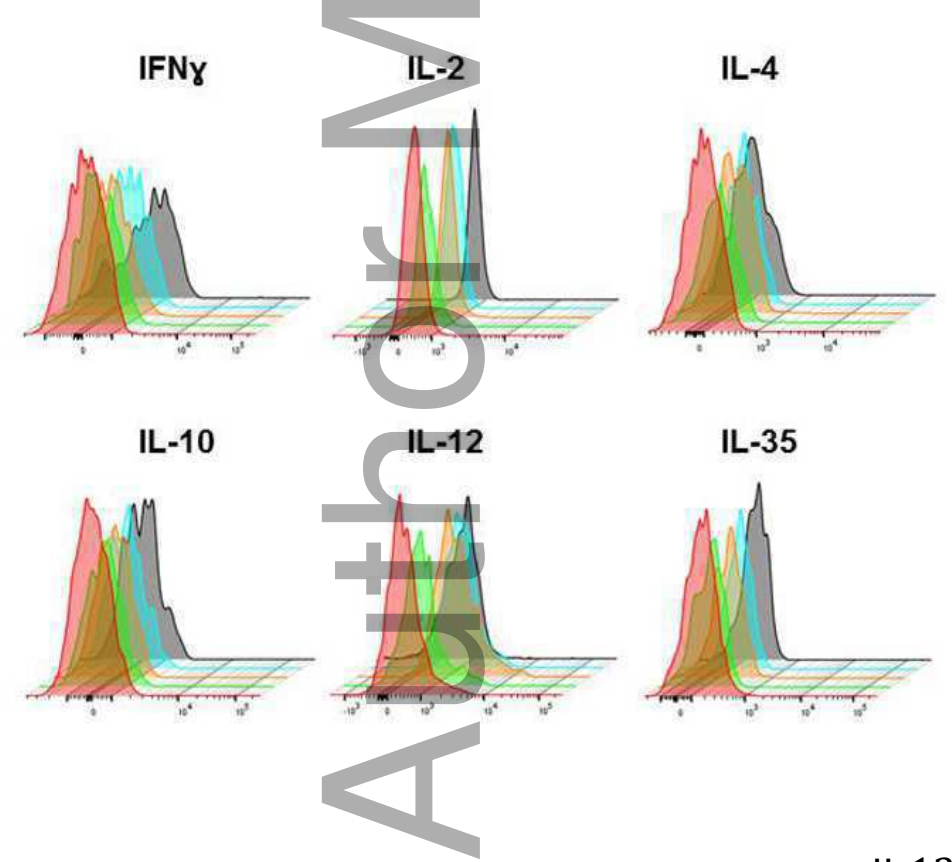
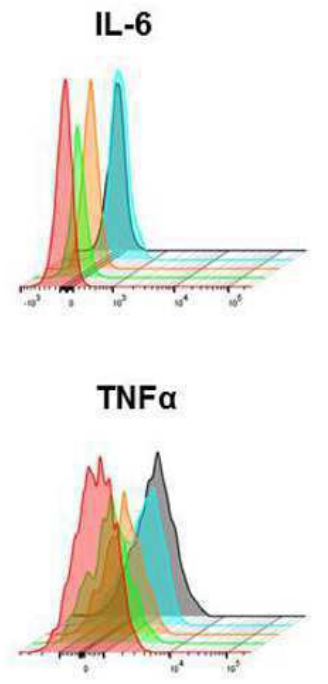

B
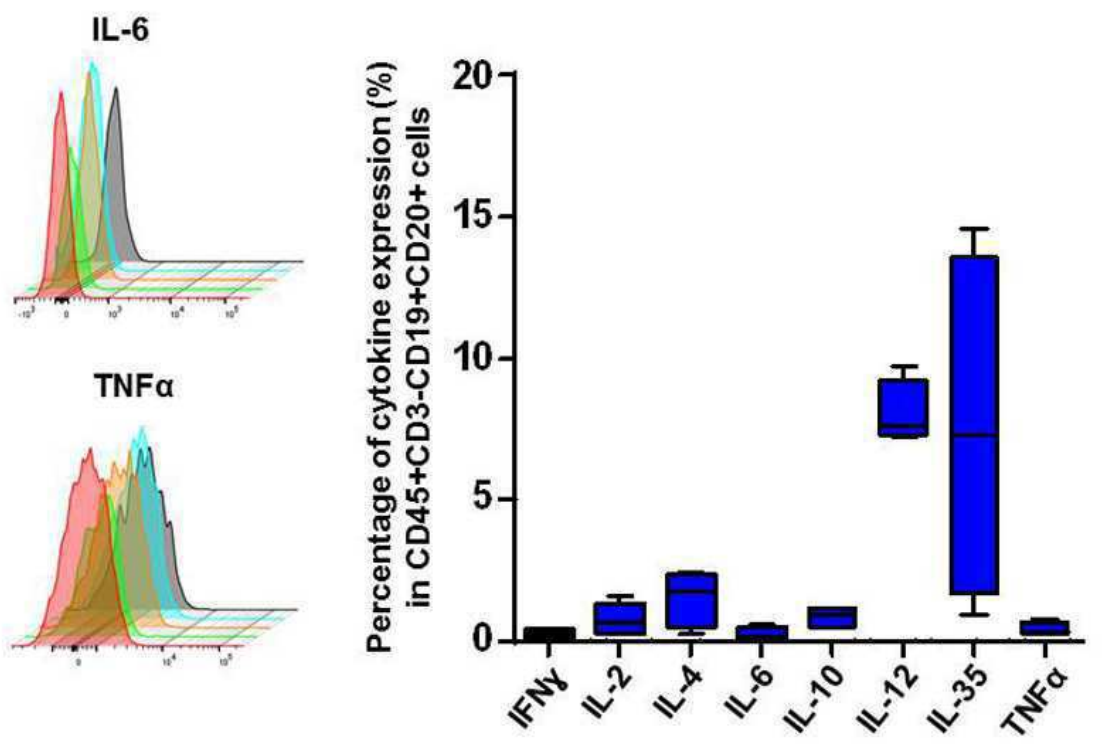

D Decidua Parietalis

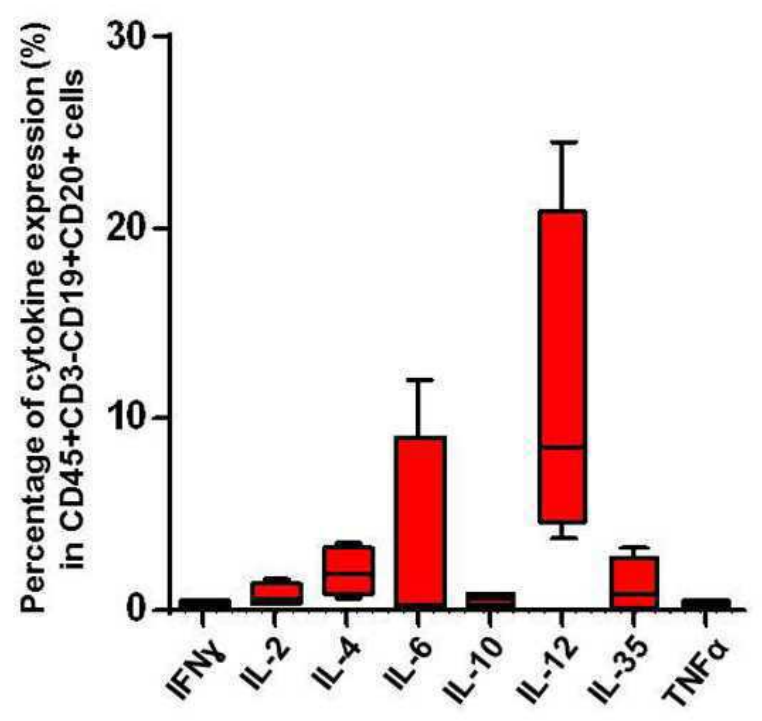

